Historic, Archive Document

Do not assume content reflects current scientific knowledge, policies, or practices. 



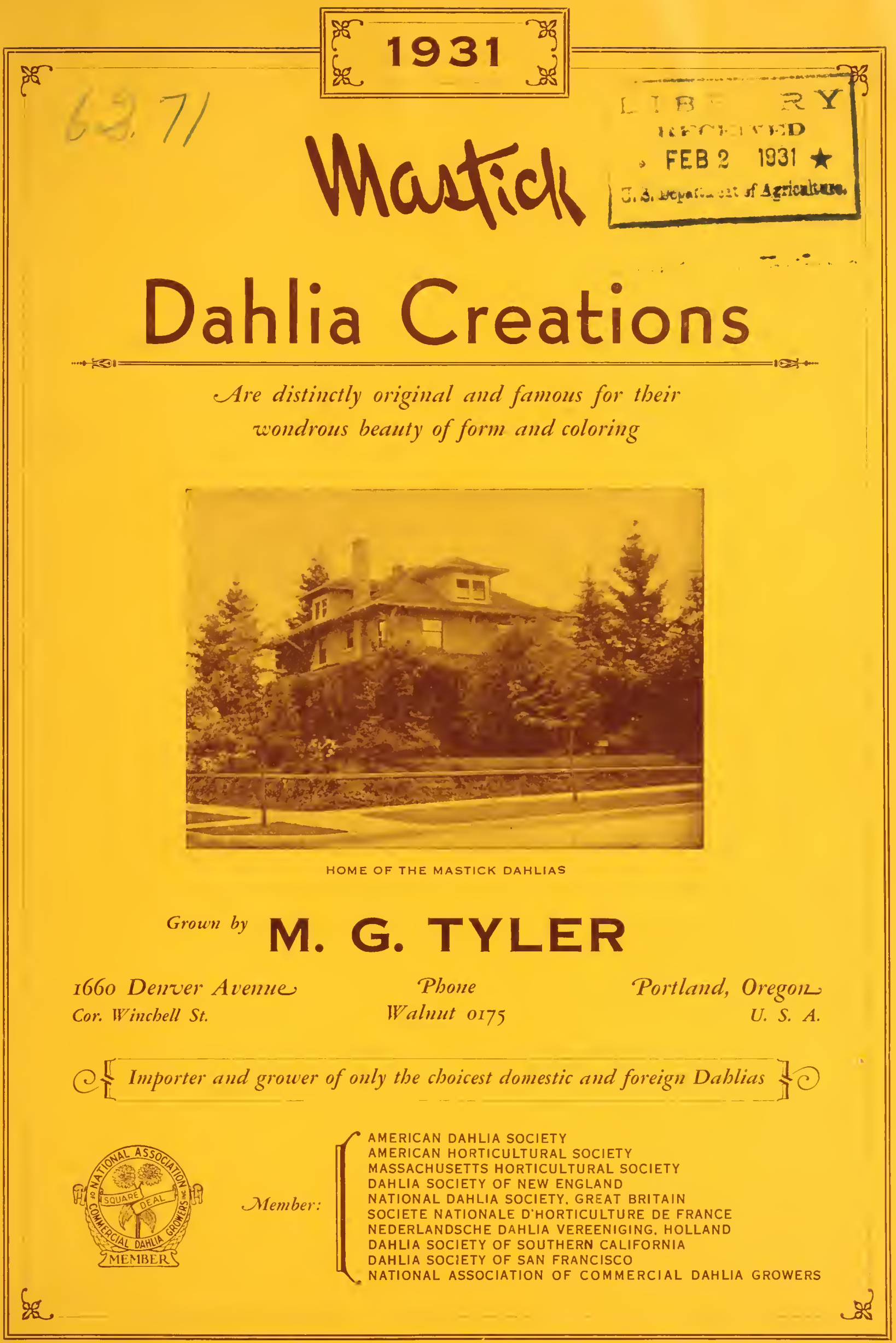




\section{Instructions $=$ Information}

To those who are unacquainted with the different classes and varieties of Dahlias we would suggest that such leave the selection to us. Send us the amount of money you wish to invest and in return we will send you those that will surely delight. Also our liberal filling of the order will more than be satisfactory.

ORDER EARLY-As orders are filled in rotation-with field-grown roots only-ordering early will insure the reservation of varieties that later may be sold out.

SUBSTITUTION-Orders are filled with varieties called for, and, unless substitution is asked, we never substitute.

TIME OF SHIPMENT-Unless otherwise ordered, tubers will be shipped between April 15th and June 1st by insured mail AT OUR EXPENSE. DAHIIAS ORDERED SHIPPED BEFORE APRIL 15TH WILL BE SENT ONLY AT PURCHASER'S RISK OF DRYING OUT, FREEZING OR ROTTING.

TERMS-Cash with order unless parties are known to us. No goods sent C. O. D. unless 50 per cent of purchase price accompanies order.

GUARANTEE-We guarantee safe delivery. We guarantee all roots to grow and to be true to name, and will cheerfully replace any that fail in either respect the following season.

REMITTANCES should be made by bank draft, check, postoffice money order or registered letter. Postage stamps accepted up to $\$ 2.00$. Coin should not be sent by letter unless registered.

ERRORS-While our system for handling orders is as near perfect as possible, yet in the rush of business errors are possible to occur, and we wish to be promptly notified of such and will at once make same satisfactory. Keep copy of your order for comparisoll.

NAME AND ADDRESS-Remember to write your NAME, POST OFFICE, COUNTY and STATE; also give STREET NUMBER or P. 0. BOX as plainly as possible. 


\section{Foreword}

It is with pleasure we hand you our annual catalog. the deseriptions in which are to be depended on, also our gardens are absolutely free from stunts or disease of any kind. Our orders are filled with field grown roots only, which we guarantee to grow and to be trne to name. Failing in either. we will gladly replace same. We prepay charges on all retail orders wherever sent.

Owing to the husiness depression throughout the comtry, we have reduced prices of many dahlias to bring them within reach of all dahlia lovers, withont lowering the guality of our introductions or our well known high standard of service.

Thanking you for past favors, and hoping for the continuance of same, we are,

Yours very truly,

II. G. TYLER,

A. T. MASTICK.

\section{Introductions \\ SURPASSING OUR MANY PREVIOUS SUCCESSES}

ALLA IV (Decorative) - A bright rich eardinal red, lightening toward the tips of the petals and deepening toward the heart of the flower, with a velvety sheen over all. Ot' good size but not immense and with tlorets placed with just enough twist to the petals to give them a graceful apperance. It is an early and constant bloomer and a good keeper when ent. Blooms are carried well above the toliage on stromg slender stems ......................... \$5.00

LOCHINVAR (Informal Decorative)-A monster, hig gold with reverse of petals jasper red in the earlier blooms lut as the season advances the red ehanges to tones of salmon and bronze. A deep flower with petals long and hroad, the inner ones tulualir and the outer ones slightly retlexed. Plants are of medium height and very sturly and the flowers are held erect on a $x$ tra good stems, and the foliage is immune to the ravages of inseets. A 1930 Roll of Honor Dahlia and to quote Mr. Hart "should make quite as good a record as Marmion." ................... \$10.00

ST. HELENS MIST (Decorative)-Perfect in tormation, linge and of good depth and a clear glistening white color are some of our reasons for claming it is one of the best white dahlias yet introduced. l'etals are broal and regular, but as ean be seen in the illustration, the flower is not at all stiff. There is a faint tinge of erenm at base of petals, giving a glow to the heart of the flower and thus enhances its heauty. stems are pertect, holding the hlooms upright far above the plant. A very protuse hoomer and most

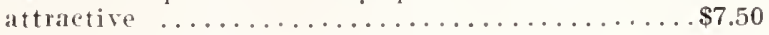

\section{Previous "MASTICK" Introductions}

ADOREE (Decorative) - "What an adorable dahlia" was the remark most frequently made at sight of this flower by visitors to our gardens, and it suggested the name. It has every good point a dahlia should have: large size, perfect form, freedom of bloom, good keeping qualities and a most exquisite color, soft rose pink, darkening towards center (which is ahwas closed), yellow at base of petals and a glistening golden sheen over all, making it especially beautiful under artificial light. Florets are long and pointed, twisting and eurling and giving the tower an unusually attractive appearance

$\$ 1.50$

ALANNAH (Hybrid Decorative)-The size, color and form of this dainty flower are unusually attraetive, while the stem is slender and ereet. Color is deep rose pink shading into pierie yellow at base of petals with a satin sheen over all, and the curly petals reflex, giving depth to the bloom. The compact, medium height bushes covered with blossoms from early in the season until frost are unsurpassed as a garden decoration. The flowers keep a long time after cutting and the foliage is remarkably free from insect pests..........50c

ARBUTUS (Decorative) - A particularly attractive dahlia of perfect form and large size. Color is the delicate pink and white of the New England May Flower, from which it derives its name. In habit it resembles Jersey's Beauty, both as to size nad shape of flower, and the extra long stem, which is almost bare of foliage. An early and constant bloomer, and always full to the

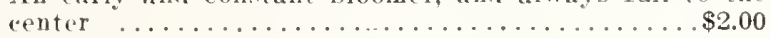

ARTHUR M. HYDE (Decorative)-Named, by permission, after our Secretary of Agriculture. This is one of the largest dahlias we have had the pleasure of introducing. And it is one of the best. The long, broarl petals are arranged so loosely as to give the flower a pleasing. graceful appearance without a hint of coarseness. stems are strong, holding the massive flowers erect. The eoloring is unique, orehis pink, with reverse of burgundy, giving the high, elosed center a distinctively charming beauty. Blooms steadily throughout the sason until frost, retaining its size and color to the last.... \$5.00

CARISSIMA (Decorative) - We cannot say too much in praise of this glistening, pure white dahlia. Large and of most attractive form, with numerous long, narrow, gracefully curling petals, it is held upright on a strong stem and challenges the attention of every passer-by. An early and continuous bloomer and we have no hesitancy in elaiming it as the most perfect white dahlia we have hal the pleasure of growing........\$1.50

ELAINE (Decorative) - A medium sized t'lower of a soft shade of old rose blended with yellow, with each petal rolled at the tips and pointed with gold. A wonderful cut tlower, and sure to be a favorite with florists. One grower spoke of it as a "glorified Futurity" ....75c 
ESPLENDOR (Hybrid Cactus) - A seedling of Ambassador, it is reminiscent of its parent in size and eoloring, but is a trifle deeper in tone and has cleft petals. I true hybrid actus, the florets are evenly rolled their full length. Strong, upright stem, free blooming and kesping qualities and good habit of growth will make this variety" an acquisition to the dahlia world....\$2.50

FANTASTIQUE (Orchid Paeony)-This introduces a trpe of diblia of an odd and fantastic slrape. The flower is semi-double with irregular eup shape florets, curled and twisted in a manner that gives the appearauce of a variety of Orchid. Its color is a deep wine rrimson tipped and bordered with glistening white, and it is borne erect on a long, graceful stem.

$50 \mathrm{c}$

GLORIEUX (Decorative)-A. D. S. Certificate of Merit. This is a dahlia of great beauty on long, strong stems. Color is deep golden rellow deepening to gamboge bronze in the eenter, each petal usually tipped white. l'lower is very full and deep and is a free bloomer. The folinge is as wonderful as the flower, being an olive green and rery dense, forming a graceful bush, quite attractive in the garden.

GRACE BURNETT (Hybrid Cactus)-Of true type and excellent stem, this beautiful large dahlia of deep velvety maroon is sure to be a great favorite when known. Petals are always rolled to the tips and slightly incurved. Good dark dahlias are searce and we think this one will be an acquisition to their ranks.... \$1.00

IVOIRE (Orchid Flowering)-Beautiful beyond belief, and of form heretofore unknown is the Dahlia "Iroire", and it has more the effect of a rare tropical Orehid than a dahlia. The waxy petals of great substance are long and pointed and eurl and twist in such manner as to almost eover the center. Color is elear, glistening ivory, deepening to eream at base of petals and a faint glow of Buttereup yellow gleams through the clustering petals at the center. It is a large flower on an 18-inch stem

LADY ALLA (Paeony)-Color is a bright searlet. Long, strong stems, carrying flower well above foliage. Large flower and a good keeper. Fragrant and more fragrant as a ent flower than on the bush.

$.50 \mathrm{c}$

LORELEI (Decorative)-One of the loveliest dahlias ever grown. Of a bright but soft shade of pure rose pink, lightening towards center to ereamy white, with each broad, gracefully placed floret distinctly outlined with deeper rose. The immense blooms are held ereet on strong stems. Very free blooming and the centers are closed until frost. Perfect in form, this dahlia attracts evervone by its sheer beauty and no one ever leaves the garden without a second look at this flower, which outshines every other pink dahlia we grow. We feej certain it will create a sensation anong discriminating growers, a Roll of 11 onol Dahlia.

$\$ 5.00$

MAC GREGOR (Hybrid Cactus)-American Dahlia Society's Certificate of Merit. IIighest Award California Dallilia Society's Trial Grounds. The flowers are large and full and carried on long, strong, upright stems. color is spectrum red, an unusual color, and beautiful in a flower; base of petals is lemon yellow. The foliage is as attractive as the blossoms, and it appears to be one of the few dahlias that is not affected by inseet pests. It is the first to bloom, and is a free and continnons bloomer until frost.

$.75 \mathrm{c}$

MAID MARIAN (Hybrid Cactus)-A rery large flower of the most beantiful shade of rose pink without a trace of pmole or yellow. Petals eurl and twist, forming a graceful bloom of indescribable charm. Stem "Ald foliage is the same as that of "Mariposa". It was closen by most of the visitors to our gardens as excelling atl others in form and eoloring.......... $\$ 1.00$

MARMION (Decorative)--Without doubt the best dahlia now on the market. This flower is of such enormous size and great depth and looks so massive among the surrounding dahlias as to dwarf them all. The long, ('ane-like stems hold the huge lolooms erect. Color is pure golden yellow with bronze suffusion on reverse of petals, and the deeper bronzy tone on the high, full center and outline of same shade around each petal enhances the beauty of the flower and gives it an unusual appearance. Florets are long, wary and eurling in such fashion as to eliminate every hint of coarseness. Form is perfect, and early and late the sturdy bushes are covered with blooms. "Marmion" was aivarded a Cer. tificate of Merit in France by "The Societe Nationale d'Horticulture de France"'...............\$1.00

MISS LONGVIEW (Hybrid Cactus)-Named for the thriving city of Longriew, Washington, and we consider it worthy to be placed before the public as a competitor of "Marmion" and prediet for it as sensational a eareer. The coloring of this huge dahlia is bright eanary yellow with reverse jasper red which suffuses the many outer rows of petals as the flower matures, giving them a soft salmon tone, while the inner ones retain the yellow eoloring, the whole flower enhanced by a glistening sheen. Its immense size (ten inches in diameter without disbudding and five to six inches in depth), long, strong stems, full center, long blooming season, make it outstanding wherever grown. Its perfect form is plainly shown in the aceompanying photograph, as are also the incurving petals with their unusual wary edges. Pro. nounced by many growers the best hybrid eactus to date

PHYLLIS ASH (Decorative)-For beauty, this flower is unrivalled. It is remarkable in form and eoloring, causing an expression of admiration from every beholder. Flowers of the softest shade of rose-pink, so blended with pale yellow as to form a magnifieent blossom of ereamy pink, with reverse of deep eream and a tiny point of pale yellow tips each floret. The form is perfeet and the flowering habit good. The stem is good and it is a remarkable keeper when eut. Flowers are seven to eight inches wide and about two and a half in depth. We predict a great future for this beauty. $\$ 5.00$

ROYCROFT (Hybrid Cactus)-One of the spiky dahlias, almost star shaped, and of an extremely odd and striking color, best deseribed as einnamon buff, deepening to tawny russet in the center. Of large size, excellent form, petals rolled to tips and never showing an open center to the end of the season. One of the first to bloom and the low-growing bushes always show a mass of perfect flowers. Foliage is unique, inasmueh as it seems to be absolutely insect proof. A distinctly different variety both in shape and coloring.......\$1.00

ST. ELIAS (Cactus)-This is the pure white eaetus all dahlia lovers are looking for, with florets of good substance, slightly elaw-shaped and incurved. Has a grand habit, fine stem, is a profuse bloomer and a good

keeper

SYMPHONY (Decorative) - A wonderfully attractive dahlia of a most unusual and original coloring, being a soft chamois overlaid alizarine pink with reverse of deel, old rose, which on the earlier blooms forms a dis tinet border $1 / \mathrm{s}$ of an inch wide around the edge of the petals. A large dahlia with broad petals which ineurve slightly and sometimes the outer florets reverse and at others roll, approaching the liybrid eactus in form. At all times it is lovely. A very free bloomer and good keeper and its stems are all that could be desiced.\$1.50

T. M. PATERSON (Hybrid Cactus)-Another red dahlia, but one of the best. Color rich bright earmine; size large, stem perfect, flowering habit excellent and keeping qualities of the best. What more can be asked of any dahlia?

$\$ 2.00$

WEST COAST (Decorative) $-\Lambda$ great big primrose yellow lightening towards the tips of the petals and deepening at the base, this dahlia looks fully its size. Holds its center well throughout the season and grows on a stem as stiff as a ramrod out of an attractive bush with dark green leaves of small size growing in eluster's, which is espeeially good for specimens or in borders. A very good keeper, but too large a flower for bouquets. . $\$ 2.00$ 


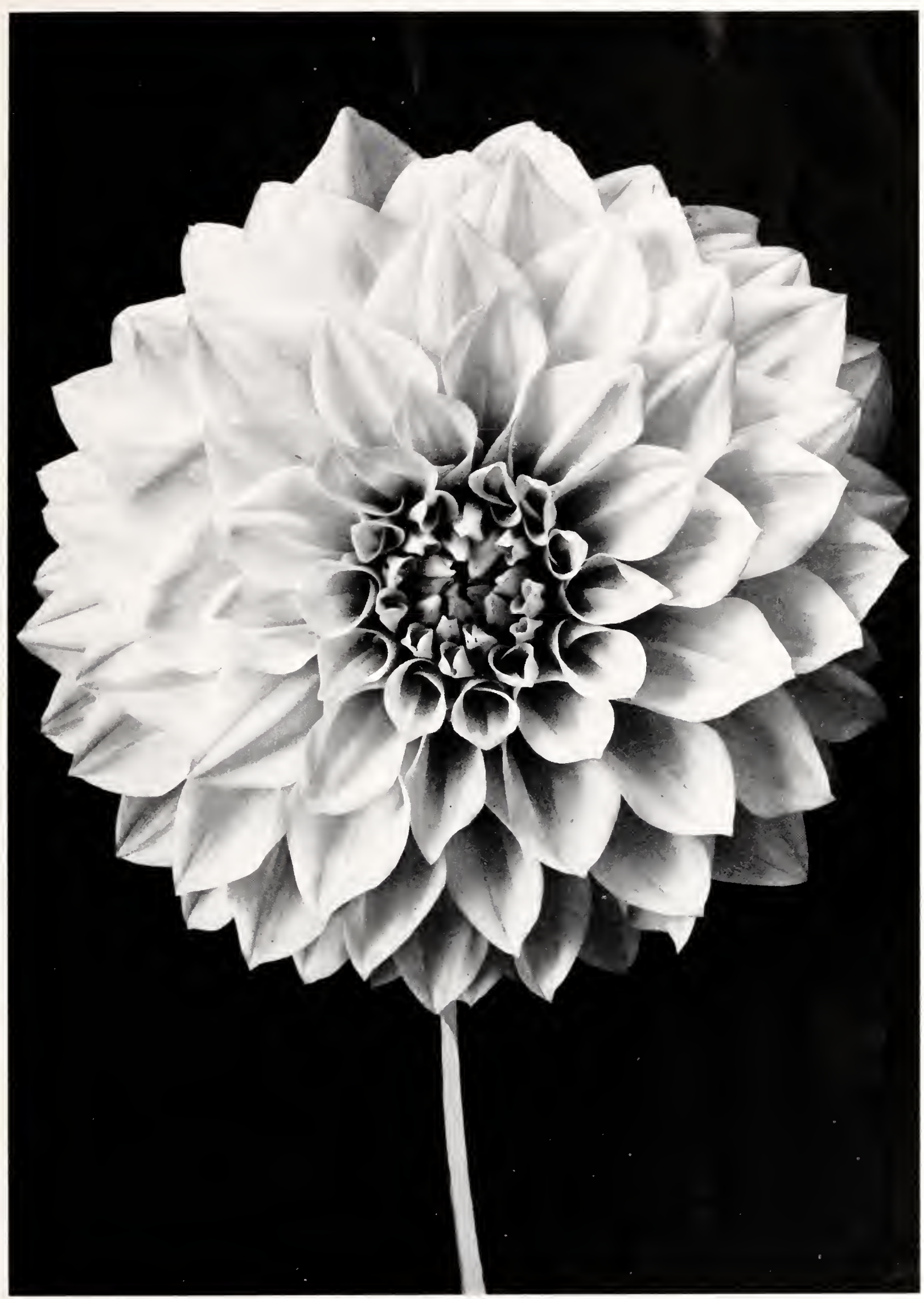




\section{Late FOREIGN Importations}

ALEONORA (Holland Incurved Cactus)-Color purple with definite llue tinges. Petals tiglitly rolled, ereet on long, strong stems. Profuse bloomer and center always full

$\$ 2.50$

CANBERRA (English Decorative) - A companion variety to the sensational dallia "Mabel Lawrence," but in the case of "Cinberra" the flowers are deep, rounded and of massive rather than wide formation. The florets are numerous and many eurl propeller-shape, greatly improving the heauty of the flower. Plants strong and free flowering. Color deep erimson-scarlet throughout

GRACE CURLING (English Decorative)-A glorious lahlia of great size, imposing and beautiful in form and color. The latter is pure white at base and to half the petals, then changing to lilae-pink and rose. Huge broad florets, bluntly tapering and tastefully notehed at tips, and forming flowers second to noue, if indeed, equalled by any dahlia yet raised. Growth of plants and flower stem hard and wiry........\$\$.00

HARRY STRUTT (English Cactus) One of our best eactus, and quite the best of its color. The flowers are large and full to the center. The plants flower with great freedom and are of capital habit, with the best of stems. Color rich, deep rimson scarlet. Altogether a good diblia and one we reeommend for all purposes ............................. $\$ 1.50$

J. EMBERSON (English Cactus)-A large flower on a long, strong stem. The form is even and florets moderately incurved. Color a blenting of deep to light pink, overlaying yellow. Plants strong and very erect in growth. Good for exhibition as well as for general purposes ....................... \$1.50

MARY MURRAY (English Cactus)-One of the best stemmed cactus dahlias to date. The flowers being carried perfeetly ereet on a hard wiry stem. The color is most attractive, being an autumn tints bronzy shade of orange scarlet to ahmost flame color at center. The form is incurved and flowers are deep and have narrow petals. Early to bloom and good till the last..... \$2.00

MARY SEGAR (English Cactus)-Clear, medium yellow, large flowers, semi-incurved narrow florets. The stems are particularly wiry, long and ereet, and freedom in flowering a feature. The plants are tall in the autumn, as the flower stems are so long, but this is our best vellow cactus to date for any purpose.........\$2.00
MINISTER BAELS (Belgian Decorative)-Seedling of "Jersey's Beauty", but more of a salmou tint than its parent, and much larger. Flower large, superb, carried on a very long and extra rigid stem. Certificate of Merit, Rotterdam ..................\$1.50

MME. ALBERT RIGOUTS (Belgian Cactus) - A true cactus with large flowers formed like the magnificent variety "Signoor," color rose Lake with center lighter, passing to white, and liglitening to the points of the tine petals. It is a very beautiful and distinct variety and altogether unusual................ \$2.00

MME. GASTON BARBANSON (Belgian Decorative)Enormous flower with broad petals srmmetrically placed. Tint altogether new, salmon veined brouze. Magnificent for exhibition as it has an upright, rigid stem ........................ $\$ 2.00$

NAGELS IDEAL (Belgian Decorative)-A new introduction truly remarkable for its new and hitherto unknown color in dahlias, violet cobalt blue. A very beautiful type of decorative with large flowers held well above the plant on long, rigid, solid stems. A variety of great promise and extra for cut flowers. Magnificent plant decorative in the garden on account of its finely cut foliage of a bluish green color. Certificates of Merit from England and Belgium... \$2.50

NAGELS MASTERPIECE (Belgian Decorative)-An inmense flower of deep golden yellow with bronze shadings in center and ou reverse. Rigid, upright stems hold the blooms erect and it is a most profuse bloomer from early till late. Certificate of Merit in Belgium ....................... \$5.00

PRESIDENT A. KREGLINGER-Enormous flowel with a rigid stem. Plants bearing splendid flowers of the most delicate coloring, clear satiny lilac rose. Magnificent alike for exhibition and for cut flowers. Certificate of Merit, Belgium.............\$5.00

RING OUZEL (English Cactus)-Quite a new color in cactus, a considerable portion of the petal being deep rose, but towards the base this ehanges to white, which shows prettily as a distinet white dise around the eentral unopened florets. Flowers are of good size, with ineurving petals and are carried on eapital long, stroug stems quite ereet ..................\$1.50

\section{General Collection}

\section{We Wish to Coll Attention to the Mony Fine Northwest Dohlios We are Listing This Yeor}

ALBERT H. VESTAL (New Decorative)-An origination of Major Eastman's. Winner of an A. D. S. Certificate. A very large decorative of glowing old rose, a pleasing color, which is not often seen. It has not a trace of any other shade. Without torcing this dahlia will grow to nine inclies and over. It untolds into a beautiful mass of twisted and curled petals with a closed center throughout the entire season. Foliage is dark green and the blooms are held a foot and a half above it on excellent stems

$\$ 7.50$

ALEX WALDIE (Decorative)- Gives immense flowers, held prect on strong stems. In color unsurpassed; a creamy wround overlaid with delicate salmon-pink, floral rays wide and full. By its bigness, color and form it eaptivates all

$.50 \mathrm{c}$

ALICE WHITTIER (Hybrid Cactus) - It is of the largest size, of perfect form, and its long, stiff stems hold the heary flowers erect. Color a heary primrose sulphur yellow. llas great substance and will keep for days

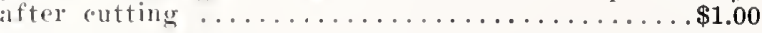

AMBASSADOR (Hybrid Cactus) - A sensational dahlia since its introdurtion. ('olor, soft rellow center with salmon, amber and pink shadings, gradually deepening toward the tips and outer floral rays. The flowers are the largest and set just right on perfect stems. A strong grower and free bloomer from early till late.75c

AMERICA'S MAID (Washington Decorative)-The only dahlia of true purple color without a trace of red we have ever grown. It has a dark, rich shade which is enhanced and beautified by a silvery reverse aud on the unopened florets in the center. Petals are broad and slightly reflexed, the center always remaining tightly closed. One of the tallest plants in the garden and flowers are held upright above the foliage. Of perfect form and habit, it is so absolutely different from every other dark purple dahlia, it is in a class by

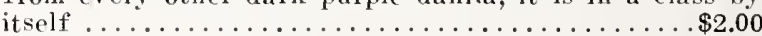

AMERICAN TRIUMPH (Incurved Cactus)-The brightest shade of oriental red without a trace of auy other color, and it has no tendeney to fade. Form is the English cactus type, center high and full. Excellent grower and the larger blossoms are held ereet ou long, straight stems. One of the best keeping dahlias at the N. Y. Show where it won the medal of the Ameri an IIome Sweepstake, for the most outstanding new seedling in the show................. $\$ 7.50$ 


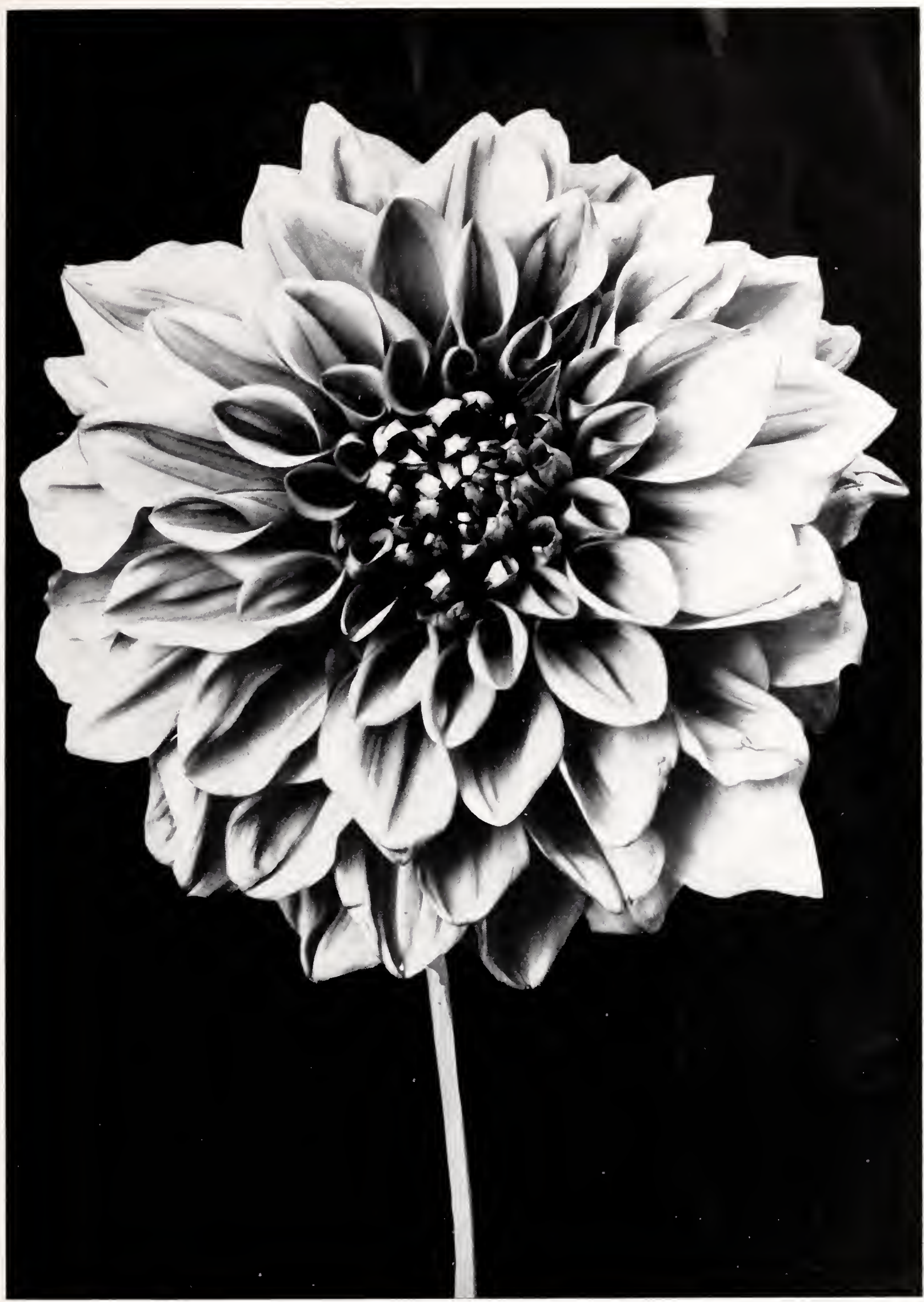


AMUN RA. THE EGYGTIAN SUN GOD (Decorative)The outer petals of the mamnoth blooms are of gror. geous sharles of copprer and orange, shading to gold and amber, and deepening in the large, full center to a rich, dark, reddish bronze. The stems are wonderfulerect and stont-and lold the blossoms well above the foliage

ANDREAS HOFER (German Cactus) - An imported varicty of exquisite beauty for table decoration. A basket of this variety exhibited at the Boston Show was one of the most admired at the exhibit. Would call it a straight catus type rather than hybrid. Flowers of medinm size are a beatiful light pink, shading to white in the eenter, Perfectly stiff stens. Free

flowering

ANNE CRAMER (Washington Hybrid Cactus) - A dark shade of primrose yellow suffused rose. A rery vigorous grower and free bloomer with immense blooms held erect above the tall plant, it is one of the most out standing in the garden. In spite of its size, it is very dainty and attractive.

$\$ 1.00$

ANN RUTLEDGE (New Califormia Hybrid Cactus) - This origination of Dr. Luther Michael is of a glowing cerise rose shade with mallow pink reverse. The splendid petal formation with just a half curl makes it an aristoerat. Unusually great depth of bloom combines with a diameter which will put it in the class of "largest blooms", and this combination on a cane stem entirely rigid and long has been the reason for the flower getting iuto the "Medal Class", at its first show-

PPELBLOSSEM (Holland Decorative) - An importa tion of the daintiest color imaginable, a pale, ereamy pink. The large flowers are composed of broad, wavy, reflexed petals and are set on top of strong, rigid stems like Insulinde and others of the newer type of Holland introductions

$.50 \mathrm{c}$

AZTEC GLORY (Decorative)-A glorious dahlia in every sense, color, form, size. This is one of the big fellows, and when the blooms attain large size the flower has an added distinction in the eurl of the end of the petal. Color is rich, clear golden yellow, witlout tints or blends. Flowers held erect on strong, stiff

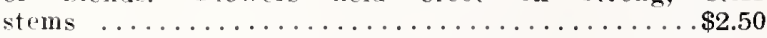

AZTEC GLORY (Califormia Decorative)-A glorious dahlia in every sense, color, form, size. This is one of the hig fellows, and when the blooms attain large size the flower has an added distinetion in the curl of the end of the petal. Color is rich, clear golden yellow, without tints or blends. Flowers held erect on strong, stiff stems

$\$ 2.50$

BARBARA REDFERN (Decorative)-A decorative with a wondertul combination of old rose and old gold. The ontside of the petals is dull gold, the reverse is delicate old rose. Both colors show at the same time. A manmoth-sized flower with great depth, borne on a heavy, stiff stem

$\$ 1.00$

BARBARA WEAR (Decorative)-The color is extremely soft and pleasing, being a pinkish lavender shading at the outer ends of the petals to cream. Stems are long and strong and the flower has good size, depth and silustance with excellent keeping qualities, which will make it in demand for florist and cut flower

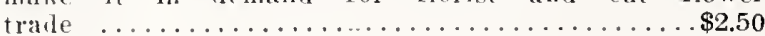

BEAU IDEAL (Decorative)-An ideal decorative of a pinkish lavender. Called by the originator a Mariposa in decorative form, we can reconmend it as being quite as lovely as Mariposa. Good habit of growth, plauts medium tall, stems long, stiff and earry flowers well albore foliage. Exhibition type............ $\$ 2.50$

BERENGARIA (English Decorative)-The originators of this dahlia consider it one of their triumphs in every way and when we saw the immense blooms growing on sturdy plants we could well agree with them. Colors are orange at center, to gold at tips, with golden sheen over all. In form it more resembles the llybrid Cactus type than the Decorative.

$\$ 1.50$
BETTY IVINS (New Decorative)-A remarkable flower of huge proportions. Petals thickly placed to form a very full flower. Color a rich salmon, orerlaid with an amber glow, showing a rosy pink reverse. Petals have that soft, glistening gleam, as reflected iu the texture of a rose. For a flower of such size, it has a remarkable stem that holds it perfectly upright, a point which has been noted by many of its admirers. Plants grow medium tall with thick, greeu foliage; stems stiff and long ............................. $\$ 3.50$

BLACK JACK (Decorative)-Deepest maroon color, almost black. Bushes are rery tall and filled with large and deep blooms from early to late season. Blossoms do not burn. Best of its color............\$1.00

BONNIE G. (Cactus)-American Cactus of the seareest shade in dablias, a true pink, paler than Delice and deeper than E. F. Hawes. The stem is fair, and this variety is a tall grower and produces very large flowers with great freedom. To a lover of pink flowers uothing so dainty and pretty has been offered since France iutroduced Delice ..................... $\$ 1.00$

BRONZE GIANT (Oregon Decorative)-The name de seribes this dahlia better than we ean. Color a rich browny bronze, almost globular in form, on stout stems. Dwarf growth .................... \$1.00

CALIFORNIA ENCHANTRESS (Hybrid Cactus)-A large bloom of good substance. A beautiful shade of pink. Good stem.......................

CAPRICE (New California Decorative)-1931 introdue tion of Mr. Mawson's which was awarded two gold medals at the Palace Hotel Show, 1930, for the best individual bloom and for the best three-year-old seedling. At the San Franciseo Auditorium it was awarded first for the best new introduction. Immense flowers both as to diameter and depth. Golden yellow shading to salmon pink. Blooms well above the foliage on long stiff stems ..................... $\$ 10.00$

CHEHALEM (Oregon Decorative)-An unusually beautiful shade of glowing creamy pink shading to cream at center. Blooms are large and stems are strong and upright. Plants grow tall and are profuse bloomers. A splendid cut flower as blooms keep well........ $\$ 1.50$

CHAMPAGNE (Decorative)-Some dahlias have only size to commend them, but this has every good attribute. Color is rare and beantiful, stem is heary and holds a massive flower absolutely upright, and the bushes are plentiful producers of blooms. Coloring is a dull golden champagne, varying to chamois.....50c

CHEMAR'S MASTERPIECE - A huge ineurved eactus flower of orchid pink or soft orehid coloring which everyone loves. The flowers are extra large, of perfect form under all conditions; are so placed on extra long stems that they show their beauty to the best

advantage

$\$ 2.00$

CHEMAR'S PURITY - A most perfect white decorative seedling from Jersey's Beauty, which it resembles in everything but color. The petals are long and straight, the renter excellent, size immense, stems extra long and stiff, holding flowers high up above a strong, sturdy plant. When the flowers first open they show a slight trace of ivory near the center; this gradually changes to a pure white at maturity.................\$2.00

CITY OF LAWRENCE (Decorative)-A large-sized flower which is also of great depth. Color is a pierie yellow shading to lemon yellow. The stems are stout and carry the heavy, round blooms well above the foliage...50

CITY OF PORTLAND (Oregon Paeony) - Color a clear, deep, rich yellow. Immense flowers that are graceful

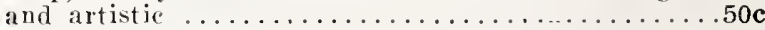
CITY OF TRENTON (Decorative)-A new variety of wonderful merit. Blooms are very large and are held erect on long stiff stems well above the foliage. The front of the petals are a rich glowing tangarine orange while the reverse is a crushed strawberry red. The gracefully curled petals give a twotoned effect, ereating an inpression of whorls of flame radiating from a full glowing center. A superb flower of great beauty and highly recommended....... \$2.50 


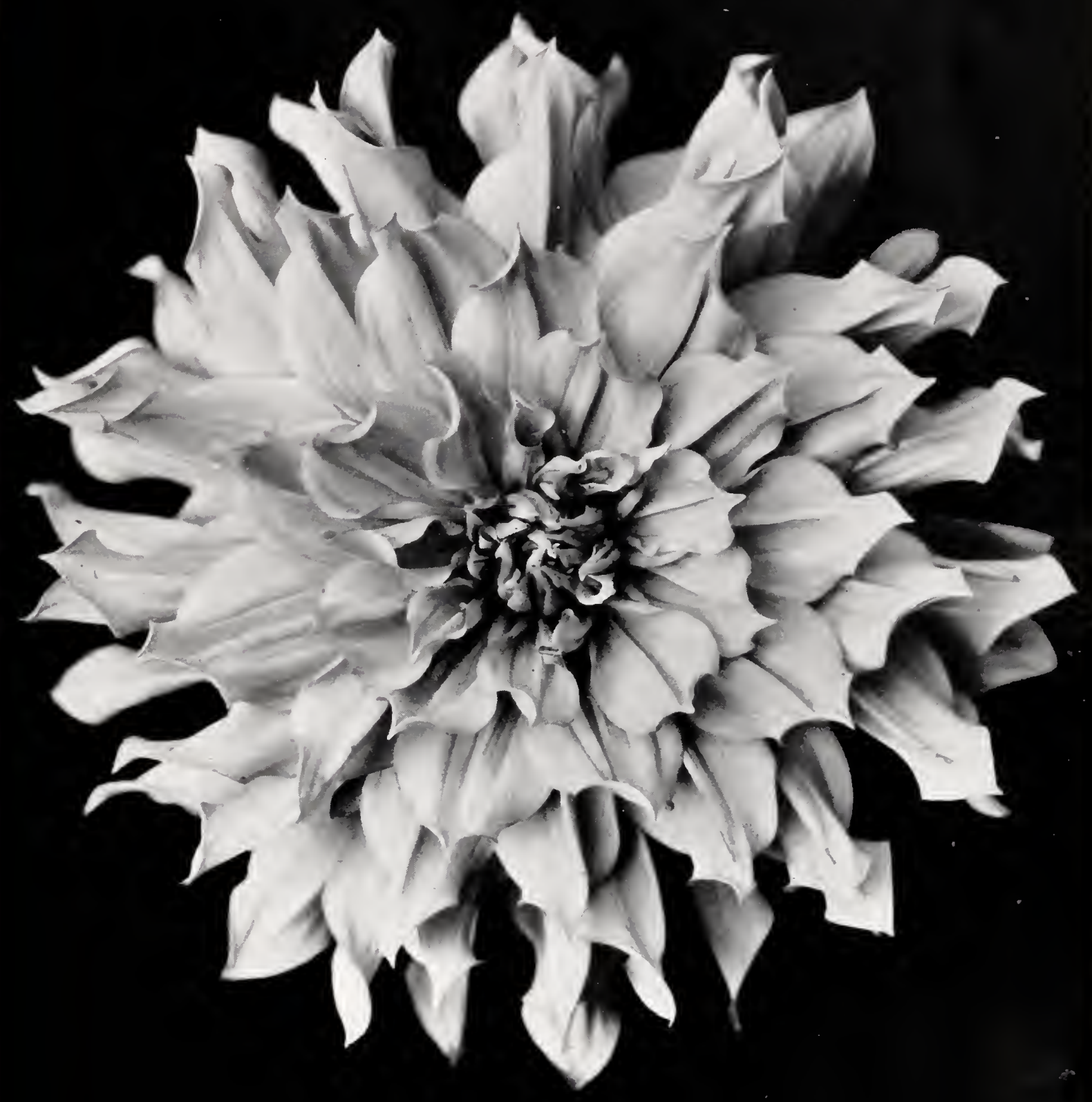


CLOUDLAND GEM (Decorative)-This large, deep dahlia with its high, rounded center opens ereamy white, lecply tipued maure pink. Is the blossom natures it changes to an exquisite shell pink, the form changing also. It thittems out and the petals curl artistically. the muler ones turning back toward the stem. It is a question which form is the lovelier. It is beantiful and holds its size until frost. Plants are tall and vigorous with lealthy foliage. "This dithlia is from the mountains of 'Temmessere

$\$ 1.00$

\section{COL. CHARLES A. LINDBERGH (Hybrid Cactus)}

Is one of the enrliest to bloom in the field. Exhibition hybricl cactus of a beantiful rose "du Barry" sharle. overlat and suffused with ohd ivory, shading off to pale gold at center. Reverse of petals light carnine piuk. In extremely free bloomer for a flower of its size. Stems rigid and straight, lark green fol:age ana good habit of growth.

$\$ 1.50$

CONQUISTADOR (Decorative) - A very large bloom of soft "reamy yellow shading to pink at base of petals. linshes are tall and rigorous and stems are long and strong. A large exhibition dahlia with unusual kepping qualities. A "best Dahlia" in the show variety. Fitra fine

$\$ 5.00$

COURONNE D'OR (French Decorative)-A wonderfully fine, large flower of a rich golden apricot color with the reverse of the petals rosy earmine, which reflects in a luminous manner to the face of the flower. It was one of the outstanding varieties in our trial gardens dnring the entire season and the bloons were always perfect, erect on stout stems............\$1.00

CRITE'S CREOLE (Oregon Decorative)-A full deep flower of dark wine red with white tips, very unusual in form and coloring.

$\$ 1.50$

DADDY BUTLER (Hybrid Cactus)-This is a large hyhrid cactus of truest form for exhibition. The many petals are perfectly rolled. The color is of the American Beauty rose shades or rosy carmine, and the reverse of the petals is a lighter tint, giving a variation of rolor. Stem is perfect ancl it is a profuse bloomer: an exceptionally fine keeper when used as a cut t'lower"

$.50 \mathrm{c}$

DAD'S FAVORITE (Oregon Decorative) - We would call this a greatly improved Grizzly, as flowers are very much like that old favorite in both shape and coloring except that they are mueh larger in size. Blooms are "rich, deep, crimson maroon. Stems are good and plants are strong growers.............. \$2.00

DAVY CROCKETT (Decorative)-Auother fine dahlia from the mountains of Tennessee of giant size and great depth. This is a trup elear searlet, the brightest in the garden, with strong, rigid stems and perfect closed center. A prolifie bloomer from early until late. Admired ly everyone ..................... \$2.00

DERRILL W. HART (Decorative)-Color "ipu(ille yollow shading to grenadine red. In cool weather almost coplele color. The plants are very strong growers and the harge well tormed flowers are held erect on the hest of stems. Greatly admired in our garden and highly recommended

$\$ 5.00$

DORIS FELLOWS (Washington Decorative)-One of the finest clean yelows with pinkish anber shadings. Strong, stealy growth, upright stem and large size. scored at $\mathrm{N}$. W. Trial Groumds.............\$3.50

DOROTHY DIX (Hybrid Cactus)-An inmense blossom of silvery pink of distinct incurved formation, centers always closed. Petals roll very eventy. Stem is per. fect, long and stiff. Plants grow tall and sturdily and proluce big thowers early and late.........\$3.50

DOROTHY STONE (Decorative)-A hinge flower of a true teep pink shade, brighter" and richer than "Kath. leen Norris" and the substance is heavier. Very full conter, petals thick and evenly placed, profuse bloomer, deep gresen leathery foliage, meslium to tall habit of growth, stem upright and strong, folwers held well ibove foliage ......................... \$7.50
DR. CURTIS HOLCOMB (Oregon Decorative)-Clear lemon yellow with delicate apricot tint on outer petals. The tight-pointed, high-centered flowers are beantiful, as they mature into large, loose, decorative forms, eack le chrling and $t$ wisting in corkscrew fashion, giving the flower a pleasing, artistic grace. The back petals are reflexed and interlaced, like a big shaggy Chrysanthemum. Plant is vigorous, with thiek, tough, leathery, insect-proof foliage.............\$5.00

EAGLE ROCK JEWEL (Decorative)-Hybrid Cactus. Cream overlaid cameo pink. Considered by many as the most beautiful in color of any dahlia. Large flowers, strong stems and free bloomer........... $\$ 2.50$

EDITH BERYL (Decorative) - A flower of medium size and perfect form of a soft buff yellow tone with reverse of pink which blends with the yellow, giving the flower a ereamy pink shade. Petals curl and twist, making a most attractive bloom. Tall plants full of flowers most desired by florists............ \$2.00

EDNA FERBER (Hybrid Cactus)-An immense dahlia with an exceptionally fine, stiff' stem. Color a glistening coral shading to old gold at base of petals. One of the first flowers to attract attention both in the field and on the exhibition table on account of its extreme beauty and size. Petals curled and twisted, making a very full flower. Nedinm to tall habit of growth, foliage dark green and thick.............\$2.00

EL DORADO (Decorative)-Size, stem and color are of the best and these three characteristics interest a persoll most in a dahlia. It is of a vivid gold coloring, which is emphasized by the deeper tones at the base of the petals . . . . . . . . . . . . . . . .

ELITE GLORY (Decorative)-It surely is a "break", in the dahlia world. None of the very best ean surpass it, and this is saying a lot when we have seeu such a year for a few very outstanding dahlias. It surely is a spectacular dahlia and must be included in all the better collectious. It is a monster flower of a brilliant rich, red color with no shadings, held perfectly erect on stiff stems. Another of those beauties that the visitors rave about. Elite Glory is here to stay for those who like size, as it has quite a reputation on winning for largest in the show as well as all kinds of other prizes... \$ $\$ 1.00$

ELIZA CLARKE BULL (Decorative) - A wonderfully good pure white, one of the largest and deepest of its class, of perfeet form, with petals just suffieiently irregular to prevent any stiffness in formation of the thowers, which are carried on strong, firm stems... \$1.00

ELKRIDGE (Hybrid Cactus)-Winner of the Garden and Home Builder Medal and Sweepstake Prize in 1926 at the Dahlia Show of the American Dahlia Society. A most beautiful white dahlia, strong stem, robust grower, great substance, free, eontinuous bloomer and one of the best commercial varieties..........75c

ELLINOR VANDERVEER (Decorative) $-A$ dahlia of great size and beauty, having every desirable quality. The blossoms are of a glowing satiny pink. Flowers are of good depth and substance and are held above a tall, sturdy bush on long, stif $t^{\circ}$ stems. Early bloomer.75c

ELSIE DANIELS (Decorative)-Color of this wonderfui dahlia is a pale violet orehid shade on the outer petals, center white, making a magnificent combination of colors; stems are long and stiff and hold the very large flowers above the foliage. It is one of the finest novelties

EMPIRE (Cactus) - A very large, beautiful dahlia of a sott raspberry red tone with perfectly rolled ineurved petals. Bushes are covered with perfeet blooms until frost. Stems fine................. $\$ 1.00$

ERNEST DE MUYTER (Belgian Decorative)-A lovely shade of eyclamen rose with a decided lavender tint. The plant is tall and sturdy and the stem is the longest we have ever seen. Strong but slender and graceful and absolutely leatless, from two and a half to three feet in

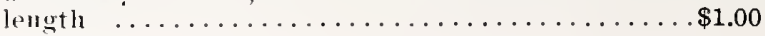




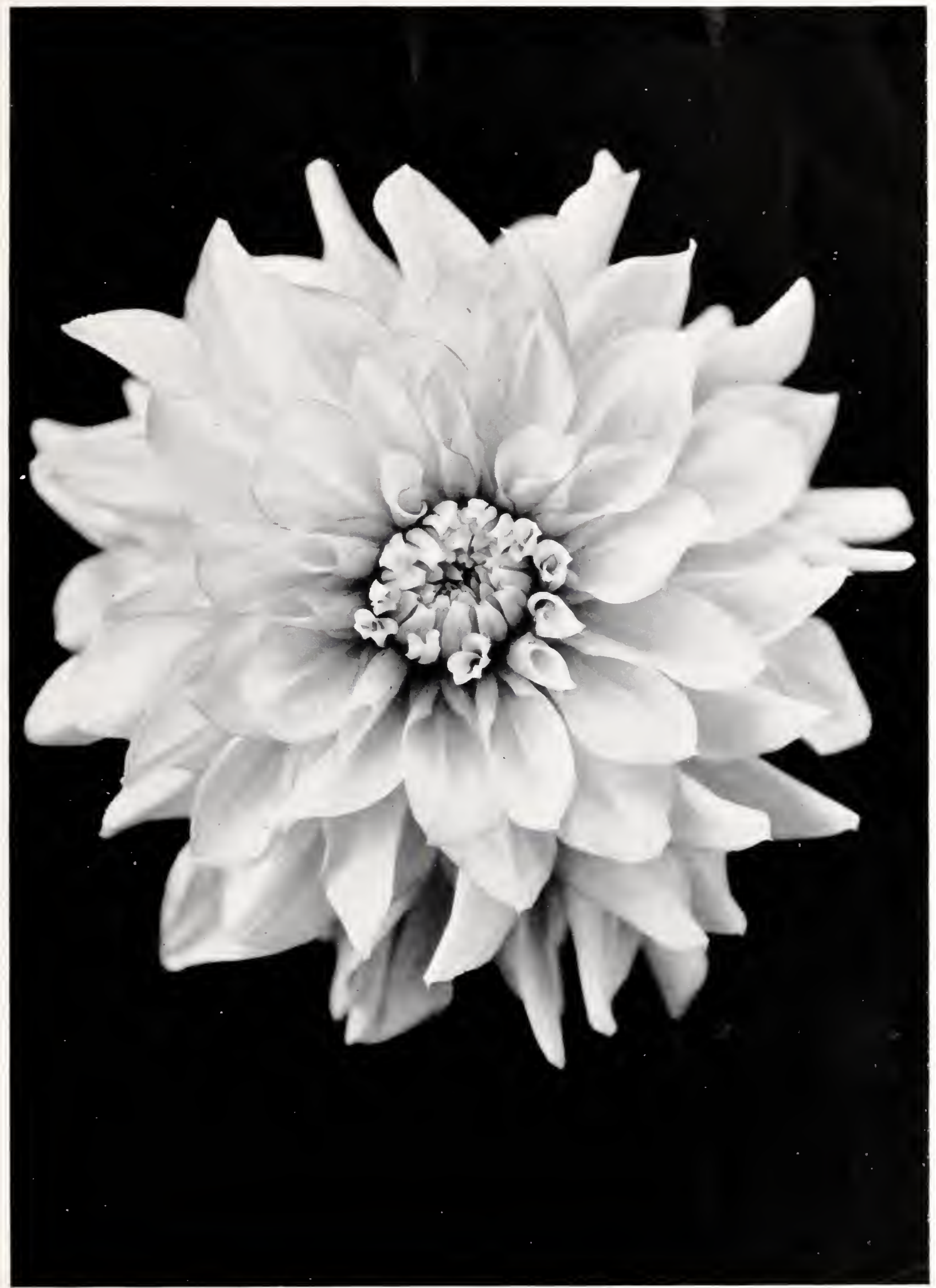


ESHCOL (California Decorative)-This is a beaty of a most strikingly handsome, dark, rich, relvety, reddish bronze, deeper by far than Amun Ra, and reminds one of all the leeper autumn shades on maple trees. Reverse of the petals is a dark wine color maroon, which adds depth and character to the whole flower, as the center is so rieh in color. Foliage is larker than the average. Ntogether a great allition to the garden. Hekl above plant on long stem.

$\$ 10.00$

EUGENIA (Hybrid Cactus) - In outstanding fluffy old rose hybril cactus whose lovely color and gracefully waved and rolled petals eommends it to beauty lovers. Blooms are of kirge size and are carried ou excellent stems above a strong growing plant. Was awarded the Garden \& Home Buihler, Achievenent Medal at Los Angeles

$\$ 1.50$

FAITH GARIBALDI (Decorative)-A deep rose-colored decorative, shading lighter on the outer petals. A flowar of great depth as well as large size, held up straight on a long, stiff stem. Always several splendid flowers ori a bush, perfect closed center. Begins blooming early and continues until frost. Fine keeper for exhibition purposes

$\$ 1.00$

FIERTE ANVERSOISE (Belgian Cactus)-One of the largest of its class and to our minds the most beautiful cactus we have ever grown. Of a tender pink tone ou outer petals to pure white in center, which is always closed. Perfect form of chrysanthemum shape and is borne on a perfectly stiff, upright stem.......\$2.00

FLAMING METEOR (Decorative)-It is large, of splendid form and unexcelled keeping qualities and is held upright on long, eane-like stcms. The color is a flaming orange scarlet, deepening to burnt orange at center, where each petal shows au amber yellow base, thus making a beautiful central halo.

$\$ 1.00$

FLAMING TORCH (Washington Decorative)-A very large flower on the very best of stems; color is a luminous flame orange. One of the most admired in our gardens and it is a profuse bloomer. Stock is always searce of this variety on account of its popularity

$\$ 1.50$

FORT MONMOUTH (Decorative)-One of the giants of the dahlia world. The predominating color is a rich crimsou maroon, with shading of bluish violet at tips of petals. The flowers are well formed of immense size, and are borne on long stiff stems high above the foliage, and look you right in the face. Does not burn and is a splendid keeper, both on the plant and when eut. Plants are strong and vigorous and are prolifie bloomers

$\$ 5.00$

FORT WASHINGTON (Decorative)-An exceptionally large, dark maroon flower. Fine for exhibition. Borne on long, straight stems above the foliage on plants of tall habit of growth and very robust.........\$1.50

FRANCESCA (California Hybrid Cactus) - An odd and original shade in dahlias best deseribed as a dull tanned rose with a distinct violet suffusion. There are old gold markings on the petals and a bluish sheen over all. There is a hint of Nature's Masterpiece in the coloring of this dahlia and also of Mrs. Eleanor Martin, and yet it stands alone as to color. Perfect stem of great strength, holding the flower well above the foliage of a very tall plant. Rather late bloomer, but prolifie after it starts to flower. Form is excellent, center closed throughout the season. As a three-year seedling it eaptured the prize for "Best Dahlia in the Show" and "the Best Basket of any Type in the Show"... .\$2.50

GLADYS SHERWOOD (Hybrid Cactus) - A pure white variety that is a real giant among dahlias. Flowers 9 inches in diameter, with disbudling. In addition to this it is free flowering and the stems are long, strong and erect

$75 \mathrm{c}$

GLENDENNING (Oregon Decorative)-Larger but sim ilar in form to Jack London, but of a deeper tone of glowing erimson with darker center. Tall grower with large flowers on strong, upright stems.

$50 \mathrm{c}$
GOLDEN EMBLEM (Oregon Decorative)-A elear, golden yellow flower of large size and perfect form, with high centers and long, wavy, recurving petals. Long, wiry stems carry the blooms erect far above foliage. Early and constant bloomer, of fine substance and keeping well after cutting. One of the best of its color....\$1.00

GOODNIGHT (Decorative)-This we considered the best of the new Broomall varieties. It is well named as the flowers are a very dark erimson or maroon of immense size. The plant grows to medium height and holds the massive blooms erect on long stiff stems. Was greatly admired in our garden the past season and recommend it highly................ \$7.50

GRANDOLA (Decorative)-A wonderful flower of brilliant orange held erect on fine stems. Good as a cut flower as well as for exhibition. Attracts immediate attention on account of its color and size.......50c

GRIZZLY, THE (Decorative) - A dark maroon red decorative. Without a doubt this is one of the best and most prolific dahlias to date. Flowers are extra large and reflexed, which makes it attractive.........75c

GUARDIAN (English Cactus)-A giant flower, earried on an upright stem as stiff as eane. Color, a glowing erimson searlet throughout. Quite the most striking variety introduced for some years, judged from a dee-

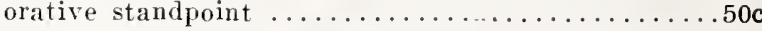

HARRIET THOMPSON (Washington Decorative)-One of the largest and most striking of any of the recent introductions. Color a brilliant orange buff face with reverse of Orient red. Petals are curled and waved, showing the reverse and thus forming a two-toned dahlia of great beauty.................. $\$ 2.50$

HARRIET WOODRUFF (Washington Decorative)-Deep rose pink unshaded is the color of this beautiful flower. Of perfect form, it stands erect and looks you in the face. Of large size and a free bloomer, it is an addition to any garden.

HATHOR (Decorative)-A dahlia of vivid Oriental colorings and atl the lure of far-off places, fascinating in its complete novelty. The predominating color is flame- not red, but verging on deep crimson, orange, and all those colors seen in glowing embers. The formation is always perfect and the stem exceptionally fine and stiff, so the large bloom looks one squarely in the face ......................... $\$ 1.50$

IDA PERKINS (Decorative)-Beautiful heary, white blossoms with cream center carried on excellent stems. A very strong grower and free bloomer on bushes about five feet high. Flowers are large with ineurved petals ....................... \$2.50

INKYO (Hybrid Cactus) - A nearly black hybrid cactus that produces an abundance of very dark red incurved blooms. Easy to have stems three feet long on this dahlia. Everyone who has grown it is enthusiastic in

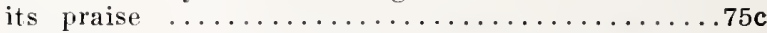

JACK HOBBS (English Hybrid Cactus) - This dahlia ereated a sensation in England when first exhibited on account of its great size and perfect form as well as for the sheer beauty of its coloring. The numerous petals continue to the very center of the bud, the flowers remaining in full beauty for days and even weeks. Color rich, clear cream at center to nearly white at tips. Borne erect on excellent stems.............\$1.00

JACK O'LANTERN (Decorative)-Large flower of scarlet with reverse of picric vellow. Finished flower is scarlet center with crown of empire yellow. Fine stems and profuse bloomer.................. $\$ 1.50$

JANE COWL (Decorative)-A massive, deep flower, with petals curled and twisted. Color a glistening bronzy buff and old gold blending to a deeper shade toward center of flower, reverse of petals a pale flesh color, giving the flower, as a whole, a warm glow. A stem of unusual strength holds this giant decorative erect over a plant of ideal growth. Foliage thick and leathery, insect resisting. Miss Jane Cowl selected this variety at the A. D. S. Exhibition in New York to bear her name. Also awarded first prize for undisseminated seedling and the Garden \& Home Builder Sweepstakes Silver Medal ......................\$2.00 


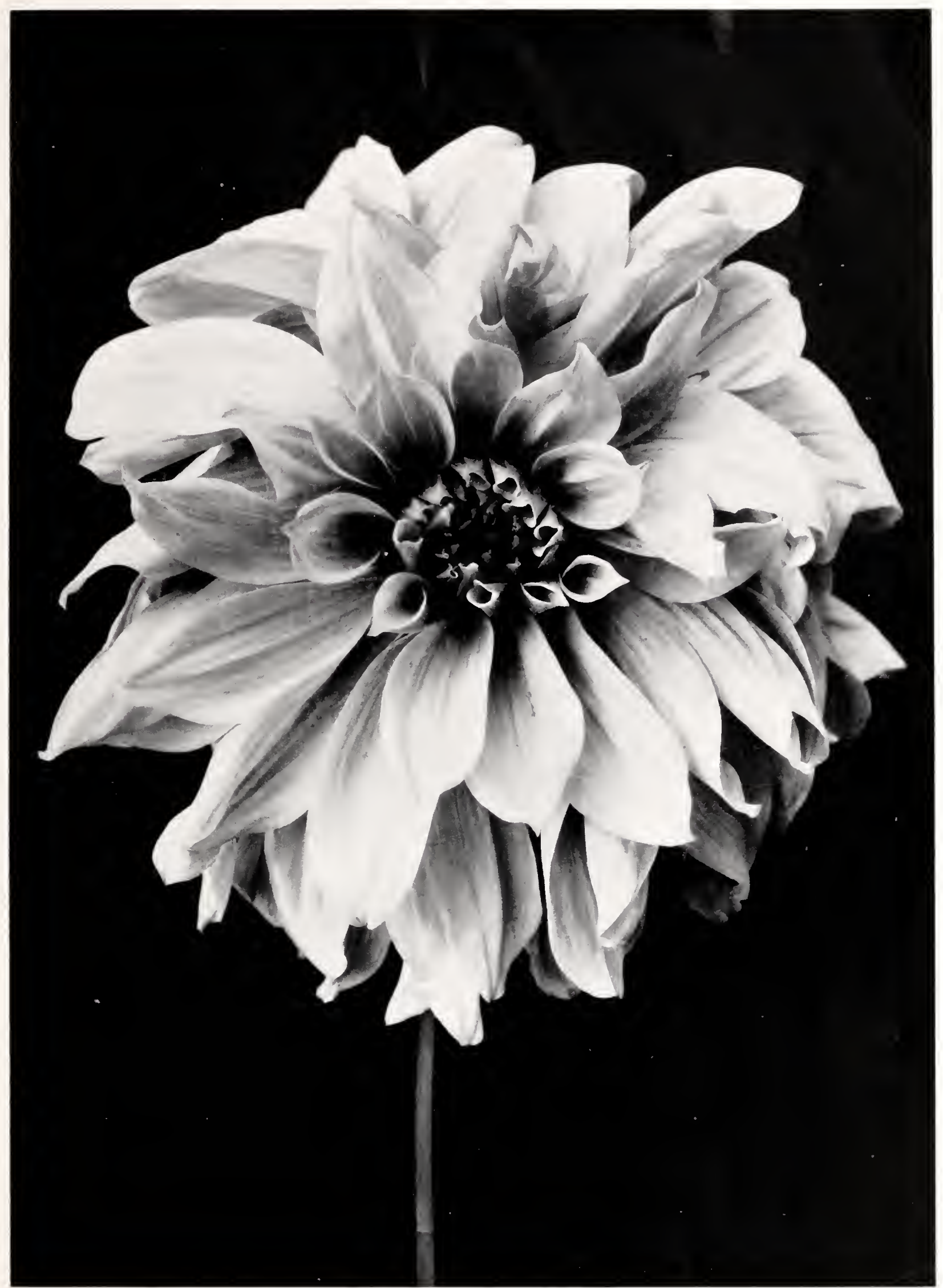


JEAN AARON (Washington Decorative)-This beautiful dahlia distinguished itself in its first year by carrying oft the blue ribbon as the best seedling in the show of the Seattle Dahlia Society and also first prize as the larenst dahlia in the show. In size it is immense, stems are perfect and hold the blooms erect, and for such a large flower it is a remarkable bloomer. The color is a pale lemon yellow, shadiug to sott rose on the outer petals. Should be in every garden.......... \$5.00

JEAN CHAZOT (French Hybrid Cactus)-This French introduction is a free, upright grower with long, stiff, wiry stems ant flowers lield well above foliage. Ot gool size and form and in color a beatitul golden bronze with faint suffusiou of nasturtium-red that in. tensifies its brillianey.

$.50 \mathrm{c}$

JEAN HARE (Hybrid Cactus) - -1 listinctive exlibition Ilybricl Cactus of peeuliar formatiou and unusual chilm. When the flower first unfolds it is a beautfiul golden yellow; as it matures it becomes an apricot buff and the outer row of petals a golden bronze. One of the most attrictive autumn colored dahlias on account of its great size and beauty. Very free bloomer, per tectly stiff, upright stems, heavy, dark green foliage

$\$ 1.50$

JERSEY'S BEACON (Decorative)-A decided novelty of Chinese scarlet with a paler reverse, giving a two-toned eftect. An exhibition flower of rigorous growth; exeellent stem

$.75 \mathrm{c}$

JERSEY'S BEAUTY (Decorative)-Very fine true pink, flowers of perfect shape, produced on loug, straight, stiff stems. Very free bloomer and a splendid keeper

$.50 \mathrm{c}$

JERSEY'S IDEAL (Decorative)-The color of this variety is best described as deep lavender. Flowers are borne tace up on top of the stems, the long petals falling lown and making a very deep flower. Tigorous grower and free bloomer and an ideal stem.... \$ $\$ 1.00$

JERSEY'S JEWEL (Decorative)-A heatiful large long-petaled variety, of sott mallow pink, produced on stems that are perfect in every way. A fine exhibition flower that has won many prizes. I beaty that everyone should grow.

$.50 \mathrm{c}$

JOY (Decorative) - A clear, silver lavender without a trace of white is the color of this exquisite dahlia. Imagine "Shudow's Lavender" without any white shading and you lave its color, and its formation is as attractive, but different. The large flower grows exactly on top of the stem like a chrysanthemum. The bush is tall and has beautiful, fernlike leaves... \$2.50

J. W. LEE (Washington Hybrid Cactus) - This dahlia of very large size is a strong grower and profuse bloomer. and the tull, graceful blooms are held erect on strong stems. Color is a blending of searlet on pale orange, giving the beautiful sunset tones, and has a halo of vellow around center.

$.50 \mathrm{c}$

KATHLEEN NORRIS (Decorative)-Color a trur rose pink, later deepening to mallow pink, but paler in the voung central petals. A bloom of gigantic proportions, jetals broal and overlapping, with twisted ends, full, tight center, and hell ereet on straight, stiff stem above a sturdy plant with dark green foliage, which is insect proot. A great bloomer and an excellent keeper. A dahlia that stands right up on the stem to he seen and admired. A winner of first honors in all the large Eastern shows in 1928. A gold and silver medial wiuner

$\$ 10.00$

KEMP'S VIOLET WONDER (Decorative)-The predominating color is a rich napthaline violet, lightening to a bluish violet at tips of petals with a lavender reverse. Flower is of perfect form and attains great size both in diameter and depth. Fine, stiff stems hold blooms well above foliage. Is a remarkaluly good keeper and does not burn. A prize winner everywhere.......\$5.00

KING TUT (Decorative)-A large blossom of rich, dark, velvety crimson, of fine formation and closed centers throughont the season. Blooms are helal erect above toliage on strong, stiff stems............ \$1.00
KITTY ROGERS (English Decorative) - A dahlia of immeuse size, the petals not being numerous but large, broad and rounded, making up completely eirenlar flowers. The color is a soft tint of pink ou a white ground. It is equal in size to Berengaria and is held erect on satisfactory stems .................. \$1.00

LADY FRANCES (New California Decorative)-Another introduction of Mr. Mawson's, which won two first prizes at the 1929 dahlia show, held at the Palace Hotel, San Francisco. The color is an unusual shade of deep old rose with golden sheen. The flowers are extremely large and well formed, stems and habit of the plant are all that could be lesired. One of the best new introductions of the season............ $\$ 10.00$

LAKE PEND OREILLE (Washington Hybrid Cactus)Flesh pink, shading darker at the outer edge, with a faint suffusion of yellow. Very graceful formation, the florets curling and waving. The stem is strong enough to hold the bloom erect and facing out and it is a free bloomer. This dahlia has attracted considerable attention throughout the Northwest wherever exhibited

$\$ 2.00$

LA RODA (Hybrid Cactus)-This beatiful varjety is an unusual shade of silvery rose pink with large, wellformed flowers held erect on strong stems. The formation is somewhat irregular, with a full center, and petals rolled at tips. One of the most beatiful flowers in our garden and very greatly admired....... \$5.00

LEMONADE (Eastern Decorative) - A flower of exhibition size of a beautiful, pale, lemon yellow. Stems are all that could be desired and plants are strong vigorous growers producing their large blooms very freely. One of the very best of its color and highly recommeniled ........................... $\$ 1.50$

LITTLE JEWEL (Pompon Decorative)-This dainty little gem is in a class by itself, a most perfect Pompon Dee. orative. It is of graceful habit of growth, extremely free flowering, a miniature decorative in form, and of a beautiful peach blossom pink in color. As a eut flower for table decoration a dozen flowers iuterspersed with a few fern fronds will outelass any other dahlia for the

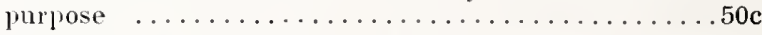

LUCKY STRIKE, NEW (California Hybrid Cactus)White dahlias are searce and there is always a demand for them. We can very highly recommend this huge variety as having all the good qualities. The incurved flower is very large and full, with long, elosely-rolled petals. Color is snow white. It is au early and constant bloomer and stem is long and good......\$1.50

MABEL LAWRENCE (English Decorative)-It is of enormous size, yet notwithstanding this and its great weight the giant stems carry the blooms as erect as if the stems were iron rods. The flowers are beautifully formed, the bluntly pointed petals being evenly arranged, tier on tier, until, as the blooms attain full development, they are perfectly circular in outline, yet to not give the slightest impression of stiffness. Color dee ${ }^{\prime}$ erimson scarlet thronghout............ $\$ 2.00$

MARIAN BROOMALL (Hybrid Cactus)-Pink and white, desceudant of Gladys Sherwood, but more cactus in shape than that variety and with better stems and lrabit. A very beatitul flower............ $\$ 1.50$

MARGARET MASSON (Decorative)-This silver rose pink flower of great size and depth is held erect on fine, upright stem and has excellent keeping qualities. 1 good exhibition variety..............\$1.00

MARGARET WOODROW WILSON (Decorative)-Iu this dahlia we have one of the finest introductions. A giant exhibition type, an opalescent piuk, face of petals creamy white, the reverse side being phlox-pink, the reflection of which gives the opalescent effect. The flowers are of perfect form, borme on stiff, sturdy stems, well above the foliage................... $\$ 1.00$

MARIPOSA (Hybrid Cactus) - A delightful shade of true pink, which is intensitied by a deeper colored center; a faint violet suffusion adds to the effect. One of the gigantic California introduetions that is blessed witl a strong, upright stem................... 
MAY TROWER (California Decorative) - A huge, deep, most artistic flower, ranging in color from palest gold to a deep golden apricot, occasionally tiped white. Stems are long, stiff and rigid and hold the blossoms erect in spite of their size. An excellent garden, ex. hibition and cut flower, unusual in formation, with great depth and substance and a rich blending of

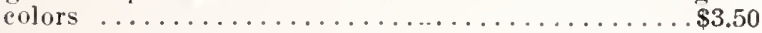

M. H. DE YOUNG (Decorative)-An immense tlower of pure old gold, brightening toward the center. This rich coloring, together with perfect form, great depth of bloom, fine stems and excellent keeping qualities, entitles this dahlia to first rank in both exlibition and cut flower classes.

$\$ 1.00$

MINNIE EASTMAN (Hybrid Cactus)-An introduction of Major Eastman's which we grew last season and greatly admired as did the many visitors to our display garden. Large blooms on the best of stems, tree bloomer, of such a brilliant color it immediately attracts the eve. Petals bright flame with undershadings of deep yellow are rolled and ineurved, forming a Hybrid Cactus of perfect torm.

$\$ 4.00$

MME. CHARLES GOOD (Belgian Cactus)-Magnificent large flower with very long stem. Carmine red, shaded chestnut, with center golden yellow and reverse of petals silvered. Slightly incurved and always in bloom

$\$ 1.50$

MME. G. VAN OOST (Belgian Decorative)-One of the most satisfactory of the foreign importations on account of its freedom of bloom, strong stems and attractive coloring, which is a clear, light like veined with purple and reverse a deep likac. Above medium size and wonderful as a eut tlower and for florists" use.....\$1.00

MR. CROWLEY (Decorative) - An exquisite shade of salmon-pink. Flowers of large size rome on stout stems on plants of very compact habit. Very free tlow ering and a splendid exhibition flower.

$50 \mathrm{c}$

MR. H. C. DRESSELHUYS (Holland Decorative) - $1 \mathrm{n}$ color it is a beautitul soft pink overlaying white. As the flower expands the pink suffuses and blends with the white, making it more lovely. Its stem is slender, strong and upright, and it will hold up as a cut flower from three to five days................50

MR. JOS WATERKEYN (Belgian Decorative) - Big blooms, almost black, reverse deep violet earmine, held aloft on strong stems. Free bloomer and a great ac. quisition to the all too few dark dahlias.........\$1.00

MODEL (English Cactus)-A model of true cactus form. Color is soft yellow base, depening to a clear, pinkish shate. Habit of best. $.50 \mathrm{c}$

MRS. ALFRED B. SEAL (California Decorative)-Flowers are huge and of great depth and substance and the color is a pure, rich, glowing old rose without a trace of any other color. They are held erect above a fine, strong, tall bush. A prize winner everywhere. A 1929 introduction, which is the largest and best of Mrs. Seal's originations

$\$ 10.00$

MRS. CARL OTT (Washington Decorative)-Color, a pale Congo pink. A perfectly tormed hybrid type; has size, refinement, and a free bloomer, and with the best of stems we guarantee this dahlia to make good anywhere ..................... \$2.00

MRS. DR. JOHN PETTY, NEW (Decorative)-This is one of the outstanding dahtias of the vear. Color is a combination of copper and yellow with reverse of red. The immense blossoms are held pertectly erect on long stems high above the foliage and are free tlowering. Grown without disbudding........\$7.50

MRS. EDWARD TAYLOR (Decorative)-Immense flower of a beautiful cerise color on rigid stems high above the foliage. One of the greatly admired dahlias. One of the best to date................... \$1.00

MRS. ELEANOR MARTIN (Decorative)-This large flower is of an unusual color, being a beautiful mnlberry suffused with gold. A perfect form, upright stems and odil coloring attracts everyone's atten. tion

$\$ 1.00$
MRS. H. J. CLOUGH (Washington Decorative)-A most attractive thower of clear pink, good size, perfect form and held erect on excellent stem above foliage of a tall. growing bush. Received 90 per cent at Northwest Trial Ground

MRS. I. DE VER WARNER (Decorative)-An immense flower on a long, strong stem. A refined, lovely color of deep mauve pink, beautifully formed, and all in all a truly wonderful variety

$.50 \mathrm{c}$

MRS. J. G. CARVER, NEW (Eastern Decorative)-Large thowers of perfeet form and great size and lepth, "arries on good stems. ('olor a rich bronze buff shade with the center wanging to golden vellow. The entire thower is covered with gold dust causing the thower to be covered with a gold sheen. Very tree bloomer and blooms always have a full tight center.... \$ $\$ 7.50$

MRS. JOHN KINGS (Washington Decorative)-Dark corinthian purple. The construction of this thower is new and attracts attention both on the lush and on exhibi. tion. It has vertect stems, which hold the thower erect

MY MARYLAND (Hybrid Cactus) - This exhibition IIy brid Cactus is of a decidedly unique coloring, a blend ing of unusually delicate pink with the faintest sugges tion of lavender; the pointed petals whorl and twist in such a manner as to blend the two colors. Excellent stems and leathery foliage. Awarded the Marvland bahtia Society's gold medal for the best undisseminated sedling exhibited at the exhibition of the New Jorser Dahlia Society in Athantic ('ity, hence its name. \$3.50

NAGEL'S ROEM (Belgian Hybrid Cactus)-Immense flowers borne aloft on very rigrid stems. Coloring Naples vellow tinted with salmon and chamois of the most delicate sharlings. This is without donbt the finest European importation of recent years. It las received three First class Certifieates.

$\$ 1.00$

NANCY SUE LANG (Decorative)-A very large fllower, red tipled gold. llabit of plant is dwart and robust. A flower that attracts immediate attention.....\$1.00

NARCISSE (Belgian Decorative)-Immense blooms: most of them one toot across and of most attractive formation with gracefully arranged petals. I'erfeet form and good stems and one of the largest in the garden. A winner in "Largest lower in the show" class. \$1.00

NATURE'S MASTERPIECE (Oregon Decorative) - A color that is hard to describe, but it is a blending ot old rose, mulberry and metallic bronze. A rich combina. tion and an odd flower, the large blooms being liekd erect on extra long, strong, upright stems......\$1.50

NEW GLORY (California Decorative) - This dahlia is all that its name indicates. Is one of the most striking ligbrid Cactus bahlias I have ever seen. It has been exhibited in many shows and has won many prizes, and is a constant attraction at every show. It is large, standing on a strong stift stem, free bloomer. A light Ox blood red with tips of petals blazed with white. The petals have a charming quilled etfect near the points, and must be seen to aprreciate it. Frows to large size, many times reaching 10 inches.

$\$ 4.00$

NEW GUINEA (Australian Cactus) - The best all-around vellow eactus to date. Of the pertect English type. l'ure golden yellow in color, stem absolutely upright, petals tightly rolled and incurved at points, and the its color ...............................

OASIS (Decorative)-This derorative is a delighteful pure pink withont any trace of yellow or lavender. $1 t$ is the pink of the old fashioned Duchess rose, only deeper in tone. A large, hut not heary flower, of long straight petals which curl slightly. Stem is long and straight. The bushes do not grow ligh and are completely smothered with blooms.............75c

ORANGE WONDER (Decorative) - A seeding of Jersey 's lieauty with all its characteristics except color, which is al rich blending of golden orange to hurnt orange. letals are broader than those of its parent and it is a larger flower and freer bloomer.

$\$ 2.50$ 
ORIENTAL BEAUTY (California Cactus) - A magnificent new hybril cactus that has to he seen to be apprecinted. For sheer beauty and pertection of torm, stem and foliage, this is the queen of dahlias. A clear brilliant rose pink, a tone leeper than Delice. Just a suguestion of a lighter tint at the tips aecentuates the beantiful incurved form. Blooms 7 to $;$ inches. Plants tall strong growers and insect proof. Its wonderful color, perfect form, tine keeping qualities, long erect stems, full center, and long blooming season, make it outstanding in any collection.

$\$ 7.50$

PAPILLON (Decorative) - $\lambda$ large flower of a beautiful shade of old rose with golden lights resembling George Walters in type and size. An incessant bloomer with strong stems which carry the flower well.

$.75 \mathrm{c}$

PARADISE (Decorative) - A bold, massive flower of the well-known George Walters type. Coloring deeidedly ditferent, being a creamy old rose suffused with gold, so blended as to give a striking brown tone. Vigorous grower, stem stiff. Fine for exhibition.........75c

PAUL MICHAEL (Decorative)-Probably the largest of the California decoratives, with a stem that carries the tlower well. Color is deep orange-buff, shading to old rose on reverse of petals. Won first prize as largest flower in botlu the San Franeiseo and Oakland Shows

$.75 \mathrm{c}$

PEARL RUGGLES (Paeony) $-d$ gem from the Santa Cruz Mountains. Color is carmine rose, shading to light pink at outer edges of petals. A wonderfully beantiful flower, carried well above toliage on strong stems

PERELLA (Decorative)-Large decorative of bright rose pink, shading lighter on the outer petals and the inner circle of petals showing a traee of lavender. Petals long, fairly flat, but not regularly placed. Stem long and stiff and grows out of the foliage and holds the flower up. Plants of medium height and are productive of an abundance of blooms from early until late season. Flowers especially attraetive under artiticial light. $\$ 1.00$

PRESIDENT WILSON (Decorative)-A large and at. tractive variety on a good stem that is sure to be a great favorite. Color is a rich crimson, each petal distinctly tipped white.

$\$ 1.50$

PRIMULA REX (Decorative)-Very light eream or primrose yellow. We regard this as one of the best deeorative dahlias in existenee. The flowers are immense, with every good quality. Far ahead of anything in its class and color. Profuse bloomer, flowers easily from 9 to 12 inches, medium to tall habit of growth

$\$ 1.00$

PRINCESS LOUISE (English Decorative)-In this eountry we would class this as a Hybrid Caetus, as the petals are rolled to the tips. The color of this large and beautiful dahlia is almost white at center, then deepening to a pretty tint of pure pink. Good stem and one of the most profuse bloomers in the garden. A wonderful cut tower and good keever..........\$1.00

RADIO (Decorative)-New. This immense dahlia is surely a wonder, bearing blooms 12 iuches in diameter without disbudling. Color is brilliant red, bordered yellow, with vellow reverse...................\$1.00

RAPHAEL (French Decorative)-Very beautiful, with flowers borne well above the foliage on the top of stems long and strong. The face of petals of bright old gold contrasts rividly with the reverse of rose lake. One of the best of the imported dahlias.

$\$ 1.00$

REGAL (California Decorative)-Conbination of autumn shades, bronze heavily suftused with dull old rose, shading to gold at base of petals, giving the effect ot burnished copper. An early and free bloomer, flowers aftaining exhibition size. Stems are straight and stitt, and plant has good habit of growth.

$\$ 5.00$

REGENT (Cactus) - In color a clear malue pink, in form an incurved American type cactus, in size one of the largest in its class. A tree bloomer, with rery good stems of the graeeful arehed trpe..........75c
RHODA (Decorative)-A most perfeetly and artistically formed little decorative. A beautiful glowing orange rose or shrimp pink shade. Extra free flowering; long, wiry stems $50 \mathrm{c}$

RICHELIEU (Decorative)-Deep relvety red, half way between elaret and roval maroon, wide petals and an upright grower. The blooms face upward and the formation of the flower is best deseribed as like that of a water lily. Good bloomer and good keeper on the plant and when cut.................... \$2.50

ROBERT TREAT (Decorative)-A most pleasing Ameriean Beauty rose color of a distinctly different shade from any other existing variety. Beautifully formed large flowers on strong stems.............\$1.00

ROLLO BOY (Hybrid Cactus)-Blooms are of great size carried ereet on strong stems and are of a delieate shade of amber, shading to old gold. For exhibition purposes it is one of the best............ $\$ 1.00$

ROSA BONHEUR (Hybrid Cactus) - A graceful combination of dainty form and elear color. Irory white center shading to a beautiful shell pink. Free blooming and splendid stem. The outer petals prettily twisted and eurled gives a graceful appearance. This, we learn, was the first American dahlia to reeeive an award in Franee

RUNA (Decorative) - A charming new orchid pink that we grew last year for the first time and found it to be evervthing the originator elained for it. For the abundance of its large blooms and lovely eolor few dahlias surpass Runa. Its long stems and unusual keeping qualities make it an espeeially desirable cut flower .

SALBACH'S WHITE (Decorative) - A superb white decorative of perfeet form. Full and deep and of wonderful substanee. Excellent stems; blooms profusely. One of the whitest dahlias in commerce........\$1.50

SANTA ANA (Hybrid Cactus)-One of the largest and best hybrid cactns of this shade. A beautiful salmonrose, suffused with gold. The plant is of medium height and a free bloomer. The flowers are held well above the dark green foliage on good stems. The petals are long and wary, which give the flowers striking form. The color of this new dahlia is most attraetive and has won the admiration of everyone wherever shown. Fine for exhibition purposes......... \$2.00

SEAL'S CALIFORNIAN (Decorative)-This huge dahlia has a beautiful blending of color-bright golden yellow at the eenter shading lighter toward the onter petals, the tips of which are suffused very lightly with a bronze rosy pink. The stems are unusually strong and blooms are fine lieepers................\$3.50

SHEILA WARD (English Decorative)-One of the most artistic and wonderfully beautiful flowers it lias ever been our pleasure to grow, the color being a light primrose vellow, heavily tipped white. The form is perfect, the flower very large. Petals are gracefully arranged, and the stem is excellent.................. $\$ 1.00$

SHUDOW'S LAVENDER (Decorative)-A very large bloom of silvery lavender, slightly shading to white. The stem is perfect, long and stiff, and holds erect the big t'lower. Excellent as a ent flower.......\$1.00

SIGNOOR (Belgian Hybrid Cactus)-Huge blooms standing well above the foliage on very long, strong stems. Brilliant, pure blood red. The flowers are most peculiar inasmuch as they have small twisted florets growing between the rows of large, incurving petals. Attracts a great deal of attention from everyone and is ontstanding in the garden................. $\$ 1.50$

SILVERADO (Hybrid Cactus) - Said by introducer to be the largest dahlia of its class ever produced. It is of white, gradually shading toward the center to a delieate silvery lavender. The stems are long and strong and the tall, well-branched bushes are always eovered with large, feathery blooms................ \$1.00 
SIMONE LAURENT (French Decorative)-Unquestionably the earliest and freest flowering white decorative yet introduced. The flowers are of fine form, good size, cn snlendid, stiff stems for cutting and hold their center throughout the season.

$.50 \mathrm{c}$

SIR JOHN CARLING, NEW (Eastern Decorative)--Here is one you have all been waiting for. It has all the good qualities you would expect in a dahlia. Size, stem, eolor and insect resisting foliage. Color is a roval purple of an entirely new shade which we have never seen in a dahlia. Does not burn in the lottest sunshine and never shows an open center. The huge blossoms are held erect on fine stiff stems and the plants are alwars covered with blossoms. Height of plants 6 to 7 feet.

$\$ 7.50$

SISKIYOU (Hybrid Cactus) - This dahlia has carried off many prizes for largest flower in show. Blooms are held erect on very strong stems. Color is pink, tinged matve. Enormous flower.

SUNNYSIDE (Decorative) - Very large blooms of a "lear sharle of grenadine red greatly intensified with metallio shadings. The immense flowers, always with full cen ters, are of beautiful formation. The petals are long and flare back, almost meeting. The stems are straight and stiff as a eane. An early and profuse bloomer making one of the most rivid spots in the garden Fine for all purposes................. $\$ 2.00$

SUSAN G. TEVIS (Decorative)-One of the largest and most perfectly formed decoratives in existence. No other dahlia elosely resembles it. The color of this stately flower is a deep shade of lilac with a bluish sheen. The plant is unusually vigorous and the foliage dark and rich. The large blooms are supported on exceptionally strong stems.

$.75 \mathrm{c}$

SYNCOPATION (Oregon Hybrid Cactus)-Large, showy blooms of cherry red and vellow. Stems are splendid. Free lolooming. Always attracts attention. Seored in the Northwest Trial Garden.

$\$ 1.00$

THOMAS A. EDISON, NEW (Eastern Decorative)-This gorgeons Formal Decorative, selected and named by permission of the famous electrieal wizard, met with his complete approval when viewed at his West Orange estate. Furthermore, it has met with universal approval in the dahlia shows of 1929. The staghorn petal formation, the dark green insectresistant foliage, the cane-stitf stems, and its thritty growing habit leave nothing to be lesired.

$\$ 10.00$

THE WORLD (Eastern Decorative) - This wonderful new dahlia was selected at the A. D. S. Show in New York by Mr. J. D. Sullivan, of the New York World. The coloring is an unusually rich, deep, rosy magenta overlaid garnet with silver shadings on edges of petals. A rich and beautiful combination of colors. Perfect, full centers. Stems are strong and erect. Foliage leathery and repellent to insect injury. This greatly admired dahlia is sure to please you........ \$5.00

THOS. HAY, V. M. H. (English Decorative)-A giant in very truth, of elear lilae color throughout; flowers deep, full and massive, with broad florets bluntly pointed. The stems carry the huge flowers with ease and the plants flower with surprising freedom. This variety is almost identical in every way (except for its lilac color) to the now famous Berengaria... \$ $\$ 1.00$

TITAN (English Decorative)-Another truly giant der orative and in actual width second to none. The florets are broad at the hase, but twist bluntly to a point. The plants are dwarf and remarkably free in flowering, when the size of each is considered. The stems are quite equal to earrying the largest blooms with ease. A seedling from Berengaria. Color uniform erimson

TREASURE ISLAND (Eastern Decorative)-One of the brightest autumn sliade dahlias we have seen. Color. bright apricot with gold, and rose suffusion and sharings. Bush growth is strong, branches readily from the ground, giving 5-foot stems, Flowers are held ereet with full centers throughout the season. A dahlia that will score high both early and late in the seasou. $\$ 5.00$
TRENTONIAN (Decorative) - A giant dahlia of a shade that is really symbolic of autumn, a wonderful blending of old gold, amber and coppery bronze with a central zone of reddish bronze. The petals are broal and well placed. Blooms are placed horizontally on top of a eane-like stem ........................ $\$ 1.00$

TRESOR ANVERSOIS (Belgian Decorative)-Very large flower of a nost exquisite shade of true violet without a trace of pink or yellow, with long, wayy, reflexed florets and held aloft on slender, upright stems. Profuse bloomer and good keeper when eut and holding its center throughout season.

UNCLE TOM (Decorative)-This comes about as near to black as any dahlia to date. The flowers are large, stem long and stiff.

$\$ 1.00$

U. S. A. (Hybrid Cactus) - A mammoth flower of an exquisite deep orange color that is very unusual in a dahlia. A very full flower carried on an excellent stem well above the foliage. Free blooming, and one that attracts great attention.

VALENTINO (Decorative)-The name suggests beauty and the flower has great size and attractive formation. It is a true salmon-pink, shading to cream at center, and is held erect by long, upright stems, and grows out of a bush of medium height. Very beautiful in our garden and attracts mueh attention........\$3.50

VELVET (Hybrid Cactus)-One of the most attractive of the dark dahlias so much sought after. The darkest tone of velvety resl, with petals long, narrow, rolled and twisted, showing old rose reverse at tips. So full that it recurves ....................... $\$ 1.00$

VICAR OF WASPERTON (English Cactus) - The base of the petals is a beautiful alizarine pink with an overlay of yellow blending to a shale of rosolane pink with an edging off to a delicate eameo pink. The center of the flower is a charming primrose yellow. This ereation is one of the best of the English importations, having gigantic size and being ideal for exhibition purposes. The florets are very long, tightly quilled and beautifully incurved

$75 \mathrm{c}$

WALDHEIM SUNSHINE (Decorative) - A true deep yetllow giant flower, yet graceful. A yellow that shows up well under artificial light. The reflex is darker and there is a rich, golden suffusion around the full, ligh center. The growth of plant is gool and strong stems hold the tlowers facing upright.........\$5.00

WALK OVER PRINCE (Decorative)-Here is a decorative that is a huge deej red, tipped yellow and petals edged yellow, a fine variegated dahlia. large blooms, great substance foliage pest proof. You will like this one if you like variegated lahlias............\$1.50

WATCHUNG SUNRISE (Decorative)-In rolor it is a golden amber with the reverse of petals showing rose fink and rach petal distinctly edged rose pink, giving it a very novel appearance. Stems long and slender, plants medium to tall habit of growth.......\$2.00

W. D, CARTWRIGHT (English Decorative)-One of the hest dallias ever raised and placed before the public by Mr. Stredwick and is a fitting eompanion to the famous varieties Mabel Lawrence, Berengaria and Sheila Ward. Color is deep orange at center to orange-yellow at tips. Form massive, yet without a suggestion of coarseness, the finished flowers loeing partially reflexed, yet building up full in the center. Best of stems, early to flower and grand in every way.......... $\$ 1.00$

WIZARD OF OZ (Decorative) - This veritable giant is a rare sharle of glowing amber pink, of soft salmon shades aud held high on strong stems. One of the finest exhibition and cut flower dahlias. A prize-winner wherever shown

$\$ 1.00$

YANKEE KING (Decorative)-It is hard to accurately describe the coloring of this dahlia, which has won so many prizes at the New Tork shows, which is a recommendation in itself. It is a bloom of deep autumn tints, with some rose on the reverse of the petals, or, as one admirer described it, intense flame with rose reverse. The blossoms are very large and held ereet on a tall, rigorons bush by extrix long, fine stems...... \$1.00 


\section{French "STELLA" Dahlias}

A new race of dahlias from France of which we have given the introducer's description. In size they are from two to three inches.

"We have given to this race, so original and artistic, the name of 'Stella' for the reason that the formation of the flowers brings to our minds the form of a star, or more preeisely an 'Etoile de Mer' (starfish). They have for the principal characteristic the pretty forward roll of the petals showing the reverse, generally of another eolor than the face. These flowers. of a fairy-like grace and delieacy without an egual in dahlias, lend themselves better than all other varieties to the ornamentation of the table, the home and for any other purpose for which flowers are used."

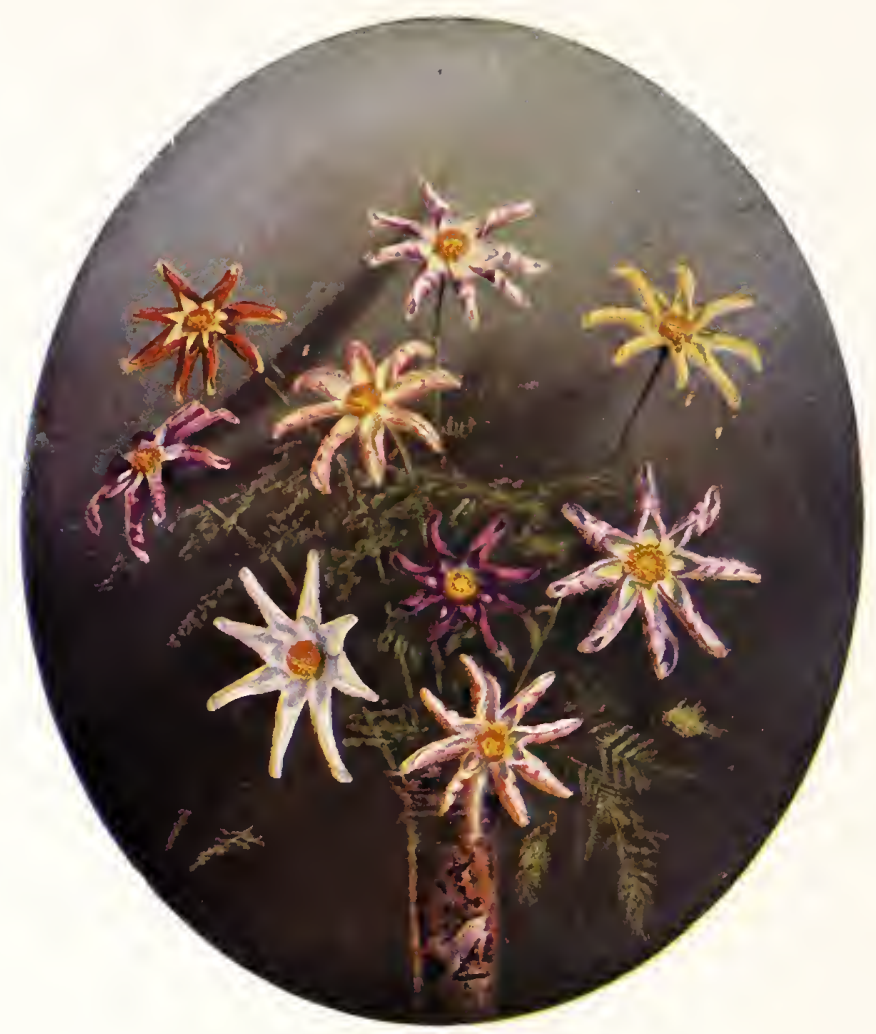

CONSTANCE-Face intense gold, reverse copper red, moiré.

ETOILE DE CASTELNAU-Face currant rose, reverse deeper rose, moiré.

ETOILE DE DESGOUTTES-Face sulphur yellow, reverse cream white to pale rose.

ETOILE D'ESPEREY-Face chamois, reverse intense garnet moire.

ETOILE DE DUBAIL-Face chamois tinted orange, reverse copper red.

ETOחE DE FOCH-Face pale yellow, reverse carmine red, moirè.

ETOILE DE LIAUTEY-Face clear canary, reverse deeper yellow, lined rose.
ETOILE DE MAISTRE-Face velvety chestnut red, reverse lighter golden yellow aureole.

ETOILE DE MANOURY-Face pure white, reverse rose lilac, moirẻ.

ETOILE DE MARCHAND-Face bishop violet, reverse silvery rose, aureole of gold at center.

INNOCENCE-Pure white.

MARIE LOUISE-Face crimson purple, reverse lilac.

M. JACQUES GALLARD-Face clear red, reverse deeper red.

ETOILE DE MARJOUIET-Face garnet purple, reverse bishop violet.

Having a large stock of these dahlias, we are listing them at the rery low priee of 50e per root. 
Mastick Dahlias

\section{G. TYLER, Dahlia Importer and Grower}

1660 DENVER AVENUE, PORTLAND, OREGON, U. S. A.

Date

Amount Enclosed

Your Name

(PLEASE STATE IF MR., MRS. OR MISS AND WRITE PLAINLY)

Post Office

Street

State

County

Shall I substitute for any that are sold out?

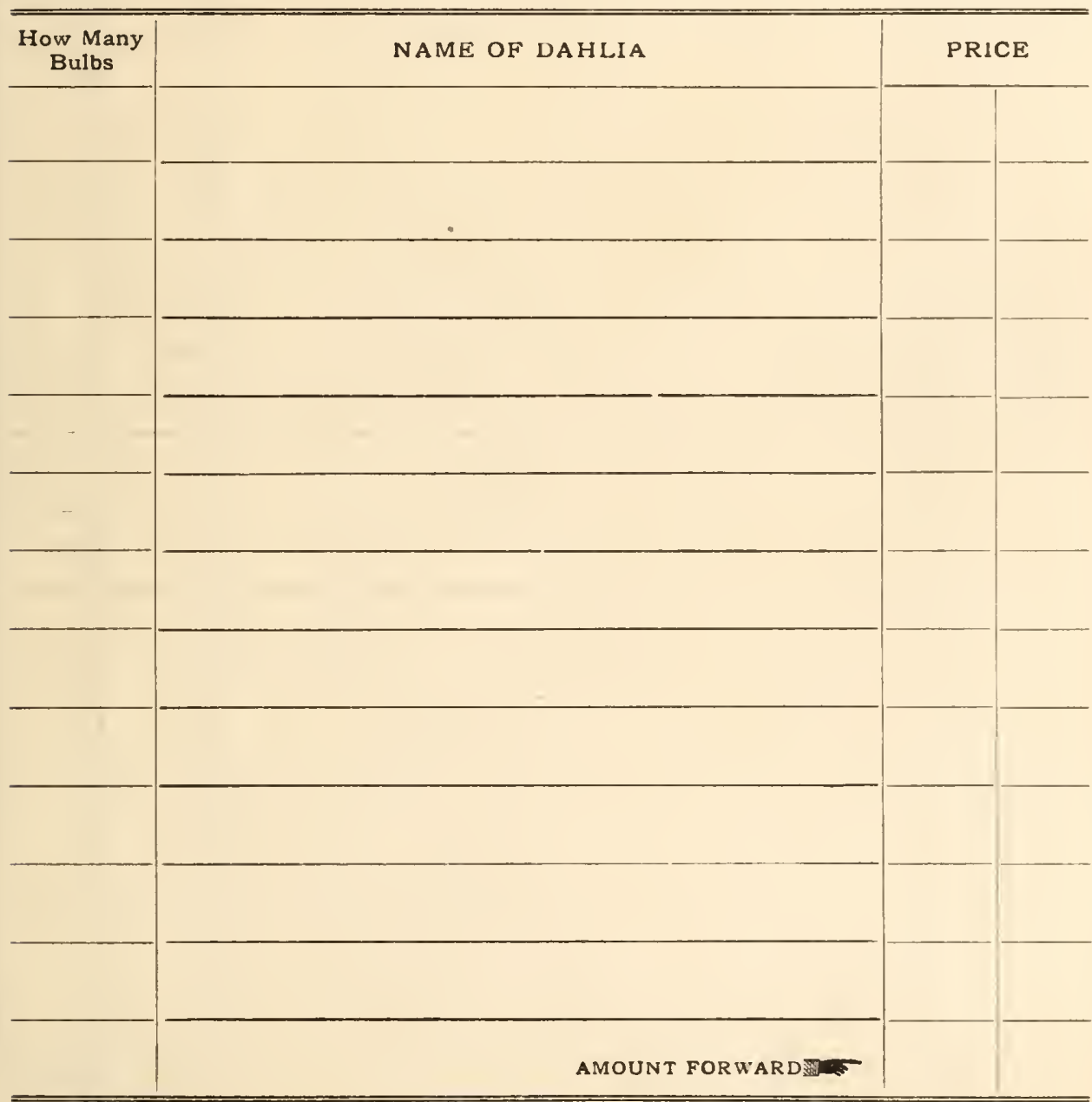




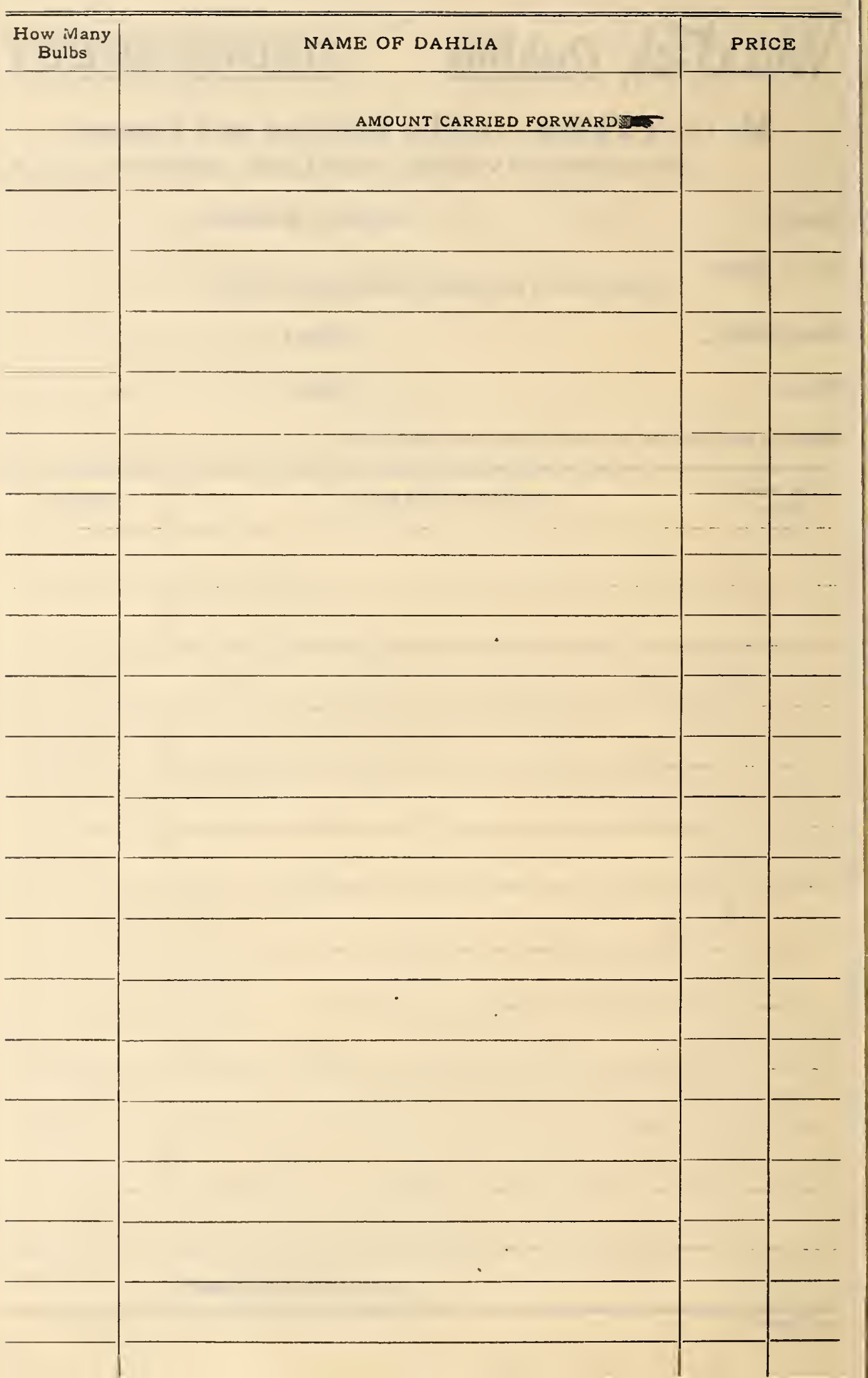




\section{Cultural Guide}

Dahlias are easily grown, requiring no special soil, treatment or skill to bring them to perfection.

They are really an Autumn flower and should not be planted too early.

They are remarkably free from disease and have few special enemies.

Plant in sunny situation, although they will do nicely in partial shade.

Prepare the soil by deep spading; if soil is sandy a shovel full of well rotted manure may be incorporated with it; if otherwise use little, if any, fertilizer before plants begin to bud. Add sand or coal ashes to heavy soil.

Drive a stake in each hole to support the plant. Lay root down flat with eye upward and next to stake, about six inches deep, and cover two inches with pulverized soil, gradually filling to level as plant progresses.

As soon as plants are large enough, pinch out the top just above the second or third set of leaves; this causes the plant to branch.

Cultivate well until buds appear, then stop all cultivation except light raking after rain or watering, just enough to break the crust of ground; only be sure and do this.

When buds appear spread manure on some fertilizer around plant and rake lightly into the soil.

Sometimes a perfectly good root with a good eye will refuse to sprout; in such cases, dig up the root and soak for 21 hours in fresh water; this usually will cause it to sprout in a reasonable time after replanting.

Unless weather is very dry and hot, do not begin watering until buds appear, then soak the ground thoroughly (not sprinkle) about once a week or ten days. Cut of all faded flowers with as much of the stalk as you can.

For extra large blooms disbud by pinching off all the buds in a cluster except the strongest one.

For cut flowers pick in the evening or early morning if possible; burn the ends of stems in any flame, or dip in boiling water for 10 seconds; after either treatment place in cold water and put in cool place free from draft until wanted.

When frozen down in Autumn, cut stalks off at the ground and dig carefully so as not to break neck of root, for the eyes for next season's growth are only found where the root joins the stalk. Store same as potatoes where they will not freeze, shrivel or rot. Turn the clump upside down to drain out any moisture that may start decay.

We are always pleased to answer any questions regarding Dahlia culture. 


\title{
DAHLIA ASSORTMENTS
}

Our Selection-from $\$ 5.00$ to $\$ 25.00$ per dozen. Send the amount you wish to invest and we will send varieties that will give perfect satisfaction and will cost less than if ordered singly.

Order Early Then you'll not be disappointed in getting what you want when you want it.

Our Annual Catalog will be sent free of charge to customers of the preceding year and to all others who request it

\begin{abstract}
OREGON DAHLIA HONORED IN FRANCE
The Mastick Dahlia "Marmion", as grown in France during the season of 1927 , received a certificate of merit from the Societe Nationale D'Horticulture de France. This is a decided honor for any flower, since to receive the award of this Society it must be far above the average of those that are granted awards in this country. In consequence comparatively few certificates are awarded by the French society.-From Florists' Exchange.
\end{abstract}

Orders are filled with clean, plump, healthy, true-toname roots, guaranteed to grow, and we will cheerfully replace any roots that fail in this respect the following season; also you will find that these roots are to be preferred to plants, being much more satisfactory in every way. 